\title{
The Role of Arabidopsis Heterotrimeric G-Protein Subunits in MLO2 Function and MAMP-Triggered Immunity
}

\author{
Justine Lorek, ${ }^{1,2}$ Thomas Griebel, ${ }^{1}$ Alan M. Jones, ${ }^{3}$ Hannah Kuhn, ${ }^{2}$ and Ralph Panstruga ${ }^{1,2}$ \\ ${ }^{1}$ Max Planck Institute for Plant Breeding Research, Carl-von-Linné-Weg 10, D-50829 Köln, Germany; ${ }^{2}$ RWTH Aachen \\ University, Institute for Biology I, Unit of Plant Molecular Cell Biology, Worringerweg 1, D-52056 Aachen, Germany; \\ ${ }^{3}$ University of North Carolina at Chapel Hill, Departments of Biology and Pharmacology, Chapel Hill, NC, U.S.A.
}

Submitted 13 March 2013. Accepted 1 May 2013.

\begin{abstract}
Heterotrimeric G-proteins, composed of $\mathbf{G} \alpha, \mathbf{G} \beta$, and $\mathbf{G} \gamma$ subunits, regulate many fundamental processes in plants. In animals, ligand binding to seven transmembrane (7TM) cell surface receptors designated G-protein coupled receptors (GPCR) leads to heterotrimeric G-protein activation. Because the plant G-protein complex is constitutively active, the exact role of plant 7TM proteins in this process is unclear. Members of the mildew resistance locus O (MLO) family represent the best-characterized 7TM plant proteins. Although genetic ablation of either MLO2 or G-proteins alters susceptibility to pathogens in Arabidopsis thaliana, it is unknown whether G-proteins directly couple signaling through MLO2. Here, we exploited two well-documented phenotypes of mlo2 mutants, broad-spectrum powdery mildew resistance and spontaneous callose deposition in leaf mesophyll cells, to assess the relationship of MLO2 proteins to the G-protein complex. Although our data reveal modulation of antifungal defense responses by $G \beta$ and $\mathbf{G} \gamma$ subunits and a role for the $\mathbf{G} \gamma \mathbf{1}$ subunit in mlo2-conditioned callose deposition, our findings overall are inconsistent with a role of MLO2 as a canonical GPCR. We discovered that mutants lacking the $G \beta$ subunit show delayed accumulation of a subset of defense-associated genes following exposure to the microbe-associated molecular pattern flg22. Moreover, G $\beta$ mutants were found to be hypersusceptible to spray inoculation with the bacterial pathogen Pseudomonas syringae.
\end{abstract}

Powdery mildew parasites are Ascomycete fungi that cause disease of a wide range of plant species. Successful pathogenesis depends on penetration into epidermal host cells by the obligate biotrophic phytopathogen, which requires the presence of particular members of the plant-specific seven transmembrane (7TM) domain mildew resistance locus O (MLO) protein family. Recessive mutations of the founder of this gene family, barley $M L O$, confer durable and broad-spectrum powdery mildew resistance via early termination of fungal pathogenesis before successful penetration (Büschges et al. 1997; Consonni et al. 2006; Jørgensen 1992). Reminiscent of fully resistant barley mlo single mutants, Arabidopsis (Arabidopsis

Corresponding author: R. Panstruga;

E-mail: panstruga@bio1.rwth-aachen.de

* The $\boldsymbol{e}$-Xtra logo stands for "electronic extra" and indicates that one supplementary figure is published online and that Figures 1, 2, and 6 appear in color online.

(C) 2013 The American Phytopathological Society thaliana) triple mutants defective in the three co-orthologs MLO2 (Atlg11310), MLO6 (Atlg61560), and MLO12 (At2g39200) are fully immune against the compatible powdery mildew fungi Golovinomyces orontii and G. chicoracearum, indicating unequal genetic redundancy between the three Arabidopsis genes (Consonni et al. 2006). By contrast, mutant versions of $\mathrm{MLO} 2$ alone confer only partial resistance to these pathogens, a phenotype that is dependent on components of preinvasive antifungal defense (Consonni et al. 2006, 2010).

Mutations in the above-mentioned barley and Arabidopsis $M L O$ genes result in additional developmentally controlled pleiotropic phenotypes. The formation of spontaneous cell wall deposits containing callose, a $\beta-(1,3)$ polyglucan, in mesophyll cells and early leaf chlorosis or necrosis occur during vegetative development in both barley and Arabidopsis mlo mutants (Consonni et al. 2006, 2010; Piffanelli et al. 2002; Wolter et al. 1993). In Arabidopsis, spontaneous callose deposition in $m l o 2$ mutants is mediated by POWDERY MILDEW RESISTANT4/ GLUCAN SYNTHASE-LIKE5 (PMR4/GSL5; At4g03550) activity, an enzyme also required for the biosynthesis of callose at wound sites and in local cell wall appositions (papillae) following pathogen attack (Jacobs et al. 2003; Nishimura et al. 2003; Consonni et al. 2010). Developmentally controlled callose deposition and early leaf chlorosis or necrosis in mlo2 mutants were found to be fully dependent on functional salicylic acid (SA) biosynthesis and signaling, which in turn are not essential for mlo2-mediated powdery mildew resistance, demonstrating that the pleiotropic effects can be genetically uncoupled from mlo-based resistance (Consonni et al. 2006, 2010).

Powdery mildew immunity conferred by loss-of-function of particular MLO proteins is conserved in various plant species (Bai et al. 2008; Consonni et al. 2006; Humphry et al. 2011; Jørgensen 1992). Other members of the Arabidopsis MLO family operate in processes unrelated to powdery mildew pathogenesis such as root thigmomorphogenesis or pollen tube perception (Chen et al. 2009; Kessler et al. 2010). The biochemical functions of the plant-unique MLO proteins remain elusive. MLO proteins are plasma-membrane-resident and constitute one of the largest heptahelical protein families in Arabidopsis, with an extracellular N-terminal domain and a cytoplasmic C-terminal domain (Devoto et al. 1999). Thus, the domain architecture and subcellular localization of MLO proteins is reminiscent of the G-protein coupled receptor (GPCR) superfamily in metazoans (Oldham and Hamm 2008; Temple and Jones 2007). In animals, GPCR activate heterotrimeric Gprotein signaling, one of the most evolutionarily conserved signaling pathways in metazoans, by relying extracellular signals through intracellularly associated G-proteins (Oldham and Hamm 2008). 
The canonical GPCR-associated G-protein consists of three distinct subunits $(\mathrm{G} \alpha, \mathrm{G} \beta$, and $\mathrm{G} \gamma$ ) which form a heterotrimeric complex in the inactive state. In animals, ligand binding to a GPCR induces the conversion of an inactive G-protein into its active conformation via exchange of GDP by GTP

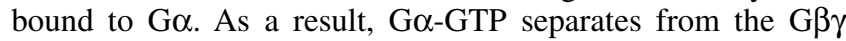
dimer and both G $\alpha-$ GTP and the G $\beta \gamma$ dimer can activate downstream effectors ultimately leading to a cellular response. The intrinsic hydrolytic GTPase activity of $\mathrm{G} \alpha$ recovers the GDP-bound state, which promotes reassociation of the complex into its inactive form. Regulator of G-protein signaling (RGS) proteins accelerate the GTPase activity of G $\alpha$. In animals, RGS proteins are cytoplasmic proteins that are recruited to the G-protein complex to support deactivation of signaling.

Compared with metazoans, the set of known heterotrimeric G-protein signaling components in plants is much simpler. The fully sequenced genome of the reference plant $A$. thaliana codes for a single canonical G $\alpha$ subunit (GPA1), one G $\beta$ subunit (AGB1), three $\mathrm{G} \gamma$ subunits (AGG1, AGG2, and AGG3), and a solitary RGS protein (RGS1) (Chakravorty et al. 2011; Chen et al. 2003; Jones et al. 2003; Trusov et al. 2007; Ullah et al. 2003). The plant RGS protein is unusual in that it contains an N-terminal region with 7TM domains. Despite its simplicity, the Arabidopsis heterotrimeric G-protein complex has been implicated in a broad range of biological processes, including seed germination, cell division, hormone sensitivity, sugar sensing, pathogen defense, and abiotic stress responses (Chen 2008; Jones and Assmann 2004; Perfus-Barbeoch et al. 2004;
Temple and Jones 2007). The unique property of the plant G $\alpha$ subunit is spontaneous GTP loading (i.e., no canonical GPCR is needed for activation). Rather, the 7TM RGS regulates the activation state of the G-protein complex (Johnston et al. 2007). However, other 7TM domain proteins may also be involved in G-protein activation. With a total of 15 members, the plant-specific MLO proteins define one of the largest families of 7TM domain proteins in Arabidopsis (Lu et al. 2009a) and, although no significant sequence similarities between mammalian GPCR and MLO proteins exist, these plant-unique proteins may play a role in plant G-protein activation (Devoto et al. 1999; Kim et al. 2002; Lu et al. 2009a; Moriyama et al. 2006).

Previous combined pharmacological and genetic studies in barley did not provide any evidence for a function of heterotrimeric G-protein signaling in MLO-mediated powdery mildew pathogenesis (Kim et al. 2002). However, these analyses were based on single-cell transient overexpression and doublestranded RNA interference-mediated gene silencing of barley $G \alpha$ but not other G-protein complex components. Moreover, the specificity of the pharmaceutical agents used is viewed critically (Fujisawa et al. 2001; Miles et al. 2004). In summary, the question of a G-protein coupling role for the MLO proteins has not been unequivocally resolved.

Consequently, in this study, we took a genetic approach to rigorously test a potential role of MLO2 as a putative plant Gprotein-activating receptor. Based on an informative set of Arabidopsis G-protein signaling mutants and mlo2 G-protein double mutants, we assessed both powdery mildew resistance
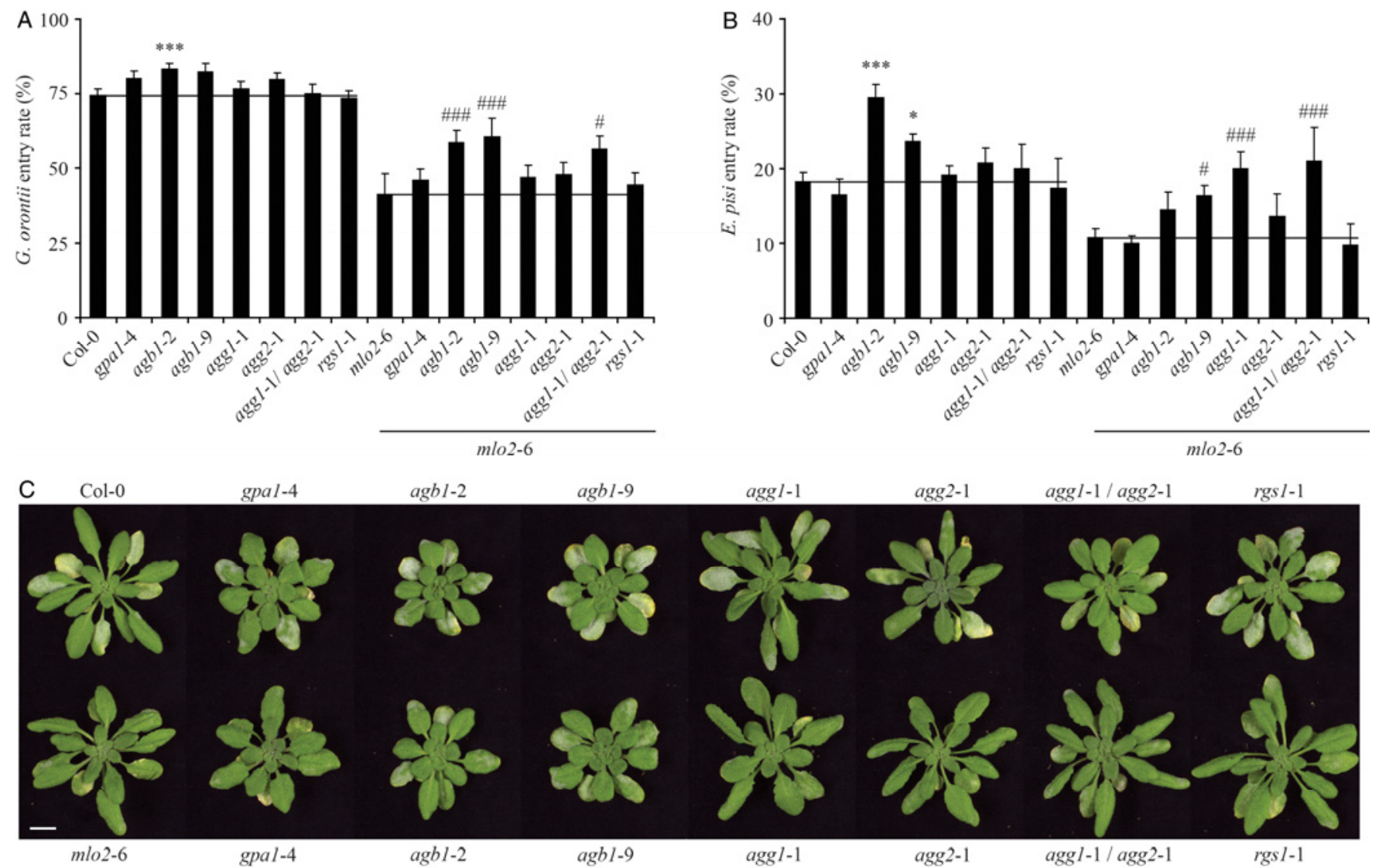

gpal-4

agbl-2

agbl-9

$\operatorname{aggl-1}$ $\operatorname{agg} 2-1$

$\operatorname{agg} 1-1 / \operatorname{agg} 2-1$ rgs $1-1$

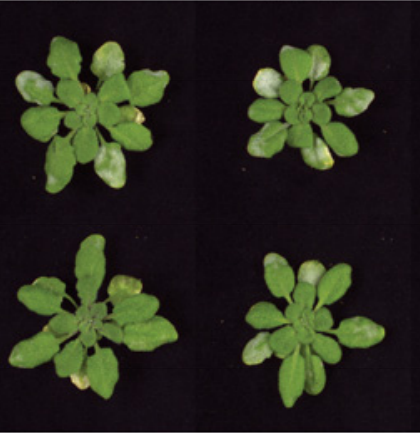

gpal -4

agbl-2
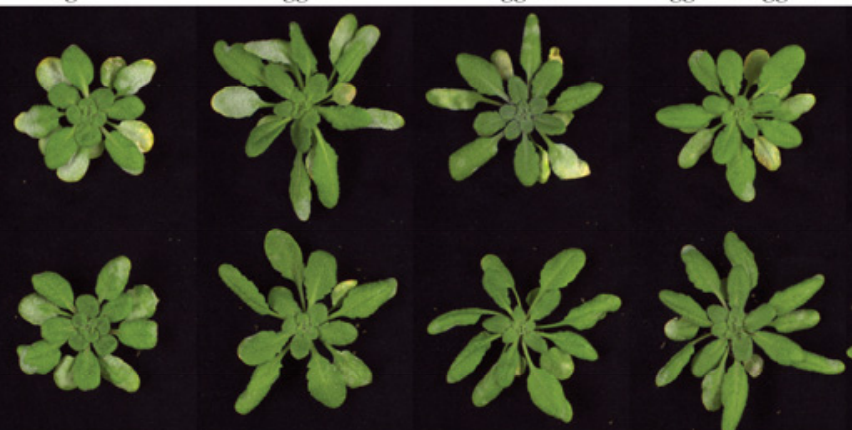

$\operatorname{agg} 1-1$

agg2-1

agg1-1/ agg2-1

rgs $1-1$

mlo2-6

Fig. 1. Powdery mildew infection phenotypes of G-protein mutants and corresponding mlo2-6 double mutants. Powdery mildew inoculations were performed with conidiospores of the respective fungus on rosette leaves of 4-week-old plants of the indicated genotypes. Quantitative analysis of A, Golovinomyces orontii and B, Erysiphe pisi entry rates scored at $48 \mathrm{~h}$ and 7 days postinoculation, respectively. Results represent mean \pm standard error of the mean of at least three independent experiments. Asterisks indicate a significant difference from the Col- 0 wild type ( $* * *$ and $*=P \leq 0.01$ and 0.05 , respectively; Student's $t$ test) and number signs indicate a significant difference from the mlo2-6 mutant (\#\#\# and \# $=P \leq 0.01$ and 0.05 , respectively; Student's $t$ test). C, Macroscopic G. orontii infection phenotypes at 7 days postinoculation. Bar $=1 \mathrm{~cm}$. 
and developmental callose deposition as readouts for MLO2 function. Overall, our data are inconsistent with a presumptive role for MLO2 as a canonical G-protein coupling protein but unravel a role for $\mathrm{G} \beta$ and $\mathrm{G} \gamma$ subunits as modulators of basal defense against biotrophic and hemibiotrophic phytopathogens.

\section{RESULTS}

G $\beta$-deficient mutants allow enhanced host cell entry by adapted and nonadapted powdery mildew fungi.

To investigate a potential molecular link between MLO2 and the heterotrimeric G-protein complex in powdery mildew susceptibility, we assessed the powdery mildew infection phenotype of Arabidopsis single mutants defective in each component of heterotrimeric G-protein signaling (Go/GPA1, At2g26300;

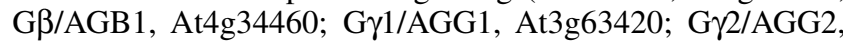
At3g22942; and RGS1, At3g26090) and the respective mlo2-6 double mutants. Given that $\mathrm{G} \gamma 1$ and $\mathrm{G} \gamma 2$ may act redundantly, the double mutant agg 1-1 agg2-1 and the corresponding agg 11 agg 2-1 mlo2-6 triple mutant were also added to the analysis, whereas the only recently published $A G G 3$ gene (Chakravorty et al. 2011) was not considered in our study. Because mlo-mediated resistance operates early and primarily affects host cell penetration, we focused on this parameter for the assessment of susceptibility of the mutants to the powdery mildew disease. Quantitative analysis of fungal entry into plant epidermal leaf cells by the adapted powdery mildew fungus $G$. orontii was performed at $48 \mathrm{~h}$ postinoculation (hpi) and revealed an increased penetration rate of the fungus on the G $\beta$-deficient T-DNA null mutant, $a g b 1-2$ (74 $\pm 2 \%$ for Col-0 versus $83 \pm 2 \%$ for $a g b 1-2$ ) (Fig. 1A, $P \leq 0.01$ ). The independent EMS mutant allele $a g b 1-9$, the gpal-4 mutant, and the agg2-1 mutant also showed elevated fungal entry rates although, for these lines, the data were not statistically significant (Fig. 1A). The increased susceptibility phenotype was more pronounced in the double mutants agb1-2 mlo2-6 and agb1-9 mlo2-6, where entry rates were $59 \pm 4 \%$ and $60 \pm 6 \%$ compared with $41 \pm 7 \%$ for the mlo2-6 single mutant (Fig. 1A, $P \leq 0.01$ ). Moreover, the agbl-2 mlo2-6 and agb1-9 mlo2-6 double mutants showed enhanced macroscopically visible powdery mildew disease symptoms at 7 days postinoculation (dpi) (Fig. 1C). Together, these data suggest a role for the $\mathrm{G} \beta$ subunit, AGB1, in preand postinvasive defense against the adapted powdery mildew fungus $G$. orontii independently of the presence or absence of MLO2.

In the compatible interaction with $G$. orontii, high pathogenicity of the host-adapted fungus may mask a subtle contribution of other G-protein complex components to powdery mildew defense, especially in the presence of $M L O 2$. Therefore, we additionally scored the penetration success of a less virulent, nonadapted powdery mildew fungus, the pea pathogen Erysiphe pisi. Consistent with the findings seen in the compatible interaction with $G$. orontii (discussed above; Fig. 1A), the agbl-2 and agbl-9 single mutants exhibited an enhanced frequency of successful entry by the nonadapted fungus (Fig. 1B). Similarly, agb1-2 mlo2-6 and agb1-9 mlo2-6 double mutants allowed significantly increased penetration by $E$. pisi (note that, similar to the interaction with $G$. orontii, entry levels of $E$. pisi are lower in the mlo2-6 double mutants) (Consonni et al. 2006). These findings further corroborate a function of the $\mathrm{G} \beta$ subunit in preinvasive defense against powdery mildew fungi that is independent of MLO2.

Although the single $\mathrm{G} \gamma$-deficient mutants as well as the agg 1-1 agg2-1 double mutant did not display enhanced powdery mildew penetration phenotypes, the triple mutant agg 1-1 agg2-1 mlo2-6 showed elevated plant cell entry by both fungal pathogens (Fig. 1A and B). Notably, unlike the agbl mlo2-6 double mutants, at $7 \mathrm{dpi}$, the triple mutant retained resistance to the compatible powdery mildew fungus, $G$. orontii, which was comparable with mlo2-6 control plants (Fig. 1C). Furthermore, the agg 1-1 mlo2-6 double mutant exhibited enhanced penetration by the pea powdery mildew fungus, which was quantitatively similar to the triple mutant agg1-1 agg2-1 mlo2-6 but higher compared with the entry rates on the two $a g b l$ mlo2-6 double mutants (Fig. 1B, $P \leq 0.01$ ). Interestingly, these effects were not observed upon infection with the adapted pathogen, $G$. orontii (Fig. 1A), which suggests differential requirements of G-protein complex components in mlo2-mediated defense against adapted and nonadapted powdery mildew fungi.

\section{$A G B 1$ and $A G G 1$ are coexpressed}

with key components of antifungal defense.

We recently reported that several genes with a documented function in preinvasive defense against powdery mildew fungi (e.g., MLO2, PEN1, PEN2, PEN3, SNAP33, VAMP722) show correlated transcript accumulation across a broad range of conditions and plant tissues ("coexpression") and proposed that these genes, together with a suite of additional genes, form a transcriptional regulon that defines a conserved functional module in monocot and dicot plant species (Humphry et al. 2010). Using a publicly accessible resource for the assessment of gene coexpression in Arabidopsis (ATTED-II), we discovered that genes coexpressed with either $A G B 1$ or $A G G 1$ show a considerably higher overlap with genes found in this transcriptional regulon than genes coexpressed with either GPA1 or $R G S 1$ (approximately two to three times as many) (Table 1). A considerable overlap of genes present in the conserved defense regulon and genes coexpressed with either $A G B 1$ or $A G G 1$ hints at an authentic role for the $\mathrm{G} \beta$ and $\mathrm{G} \gamma 1$ subunits in plant immunity. The fact that $A G B 1$ and $A G G 1$ are not integral parts of the previously identified conserved defense regulon suggests that these two G-protein subunits play a minor role in plant immunity. This is consistent with the weak but reproducible phenotypes observed with the respective mutants in our pathogen infection assays (Figs. 1A and B).

mlo2-mediated developmental callose deposition and $\mathrm{SA}$ accumulation are impaired in the $\mathbf{G} \boldsymbol{\gamma} \mathbf{1}$-deficient mutant.

The biochemical function of MLO proteins during powdery mildew host cell invasion remains currently unknown. Thus, we cannot rule out the possibility that MLO proteins operate as G-protein-activating receptors in normal plant physiology

Table 1. Number of top 300 genes co-expressed with G-protein components present in a previously described antifungal defense regulon ${ }^{\mathrm{a}}$

\begin{tabular}{lcccc}
\hline Gene & $\begin{array}{c}\text { Entire regulon } \\
\text { (406 genes) }\end{array}$ & $\begin{array}{c}\text { Co-expressed with } \\
\text { MLO2/PEN1/SNAP33 (107 genes) }\end{array}$ & $\begin{array}{c}\text { Co-expressed PEN1/SNAP33/VAMP722 } \\
\text { (282 genes) }\end{array}$ \\
\hline GPA1 & 31 & 15 & 23 & 9 \\
AGB1 & 91 & 32 & 23 & 62 \\
AGG1 & 90 & 46 & 39 & 39 \\
RGS1 & 43 & 18 & 11 \\
\hline
\end{tabular}

${ }^{\text {a }}$ Top 300 genes co-expressed with GPA1, AGB1, AGG1, or RGS1 were obtained from ATTED-II. For details on the defense regulon, see Humphry and associates (2010). 
but are co-opted for a G-protein-independent activity during fungal pathogenesis (Panstruga and Schulze-Lefert 2003). In such a scenario, the contribution of G-proteins to MLO activity would remain undiscovered in powdery mildew infection assays. Thus, we sought for readout of MLO2 function that is independent of the involvement of any pathogen. When grown under pathogen-free conditions, mlo2 mutant plants show spontaneous callose accumulation in leaf mesophyll cells. This phenotype is under developmental control and is detectable from 6 weeks onward (Consonni et al. 2006, 2010). To test whether heterotrimeric G-protein signaling contributes to this mlo2-associated but pathogen-independent process, callose deposition in leaf mesophyll cells was analyzed in noninfected rosette leaves of 6-week-old Col-0 control plants, G-protein single mutants (gpal-4, agbl-2, agb1-9, agg1-1, agg2-1, and rgs 1-1), and the respective mlo2-6 double-mutant plants. Similar to the Col-0 wild type, G-protein single mutants exhibited no callose deposition, whereas the majority of the corresponding mlo2-6 double mutants behaved like mlo2-6 control plants and developed numerous spontaneous callose deposits (Fig. 2A). Interestingly, the agg1-1 mlo2-6 double mutant showed markedly reduced callose accumulation, indicating an involvement of the G $\gamma 1$ subunit, AGG1, in the developmentally controlled biosynthesis of callose in the mlo2-6 mutant (Fig. 2A).

The formation of callose deposits in mlo2 mutants requires the PMR4/GSL5 callose synthase, an enzyme best known for its role in the biosynthesis of the $\beta$ - $(1,3)$ polyglucan at wound sites and in papillae following pathogen attack (Jacobs et al. 2003; Nishimura et al. 2003). To investigate whether the $\mathrm{G} \gamma 1$ subunit has a general function in callose biosynthesis and also contributes to wound or papillary callose depositions, we determined callose accumulation after leaf wounding and subsequent to inoculation with the nonadapted powdery mildew fungus E. pisi. Compared with Col-0 and mlo2-6 control plants, wound- and pathogen-induced callose accumulation was unaltered in the aggl-1 single and the agg1-1 mlo2-6 double mutant (Fig. 2B and C). These findings indicate that the $\mathrm{G} \gamma 1$ subunit is dispensable for localized PMR4/GSL5-generated callose formation in response to wounding and pathogen challenge. Instead, the data suggest a specific role for AGG1 in mlo2-dependent developmentally controlled deposition of the $\beta$ - $(1,3)$ polyglucan.

Spontaneous callose formation in the mlo2 mutant depends on functional SA biosynthesis and signaling, because double mutants defective in both $M L O 2$ and components of the SA pathway are suppressed in developmentally controlled callose deposition (Consonni et al. 2006). Moreover, mlo2 mutants display elevated levels of free and total SA in the course of development. The timing of the increase in SA levels correlates with the onset of spontaneous callose deposition (from 6 weeks onward) (Consonni et al. 2006), suggesting a molecular link between SA accumulation and callose deposition. There-

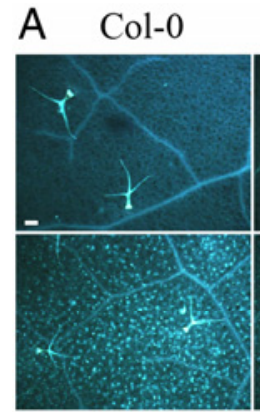

mlo2-6 gpal-4

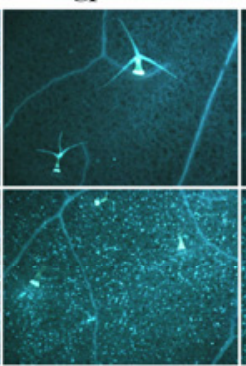

gpal-4 agbl-2

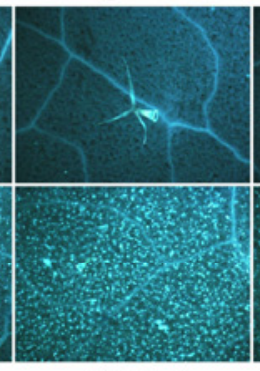

agbl-2

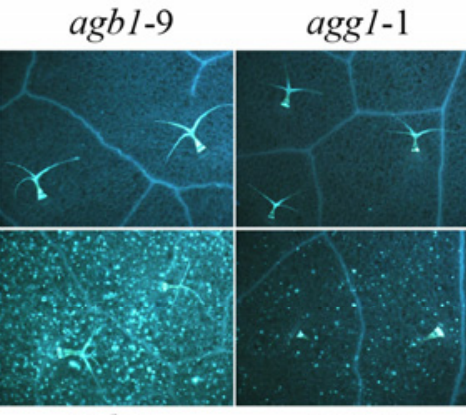

agbl-9 $\operatorname{agg} 1-1$

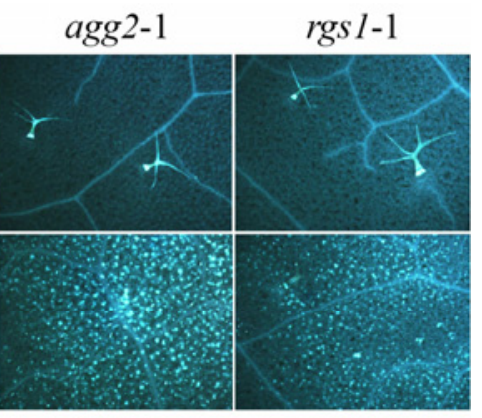

$\operatorname{agg} 2-1$

rgs $1-1$

mlo2-6

B

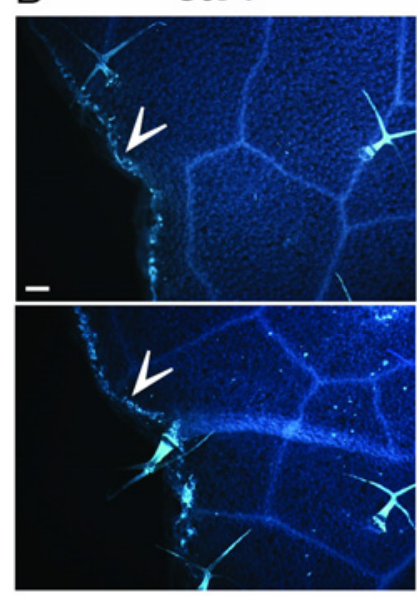

mlo2-6

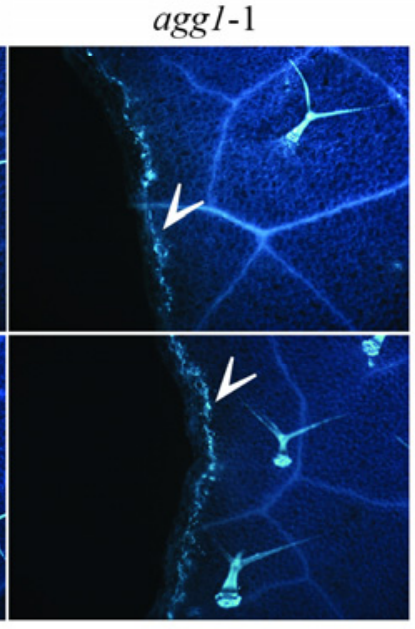

agg 1-1 / mlo2-6

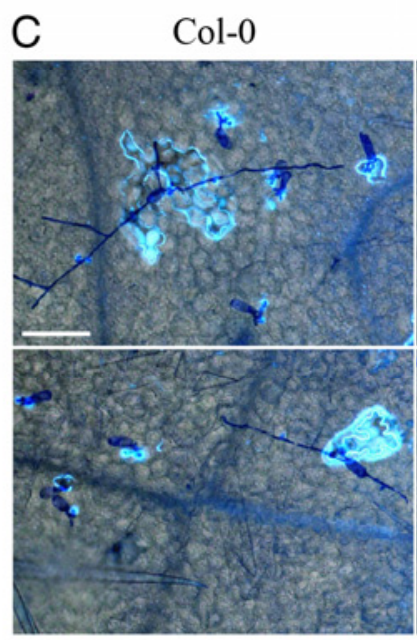

mlo2-6

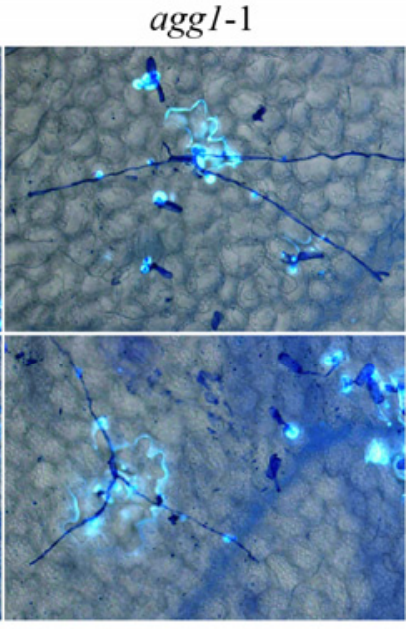

agg 1-1 / mlo2-6

Fig. 2. Callose accumulation in rosette leaves. Callose was stained with aniline blue. A, Representative micrographs demonstrating spontaneous callose deposition in leaves of 6-week-old plants of the indicated genotypes grown in pathogen-free conditions. The experiment was repeated at least three times with similar results. Bar $=100 \mu \mathrm{m}$. B, Leaves from 4-week-old plants of the indicated genotypes injured with forceps showing callose deposition at wound sites (= arrowheads). The experiment was performed twice with similar results. Bar $=100 \mu$ m. C, Four-week-old leaves from plants of the indicated genotypes at 7 days postinoculation with the nonadapted powdery mildew fungus Erysiphe pisi exhibit callose deposition at sites of fungal interaction. Fungal structures were stained with Coomassie Brilliant Blue. The experiment was performed once. Bar $=100 \mu \mathrm{m}$. 
fore, we reasoned that reduced SA levels might account for the impaired spontaneous callose accumulation in the aggl-1 mlo2-6 mutant and determined SA concentrations in uninfected 6-week-old mutant plants. Consistent with previous results (Consonni et al. 2006), the mlo2-6 mutant displayed increased free (approximately 3-fold higher) and total (approximately 10-fold higher) SA levels compared with Col-0, while SA levels in the aggl-1 single mutant were indistinguishable from the wild type (Fig. 3A). In the agg $1-1$ mlo2-6 double mutant, concentrations of free SA were intermediate between Col-0 and the agg1-1 mutant, whereas levels of total SA were similar to Col-0 wild type and, thus, strongly reduced compared with the mlo2-6 single mutant (Fig. 3A). These findings suggest that the $\mathrm{G} \gamma 1$ subunit, AGG1, positively contributes to developmentally induced SA accumulation in the context of the mlo2-6 mutant; which, in turn, explains the reduced number of callose deposits in the agg 1-1 mlo2-6 double mutant. To investigate whether the agg 1 mutant has a general defect in SA accumulation or biosynthesis, we quantitatively assessed SA accumulation in Col-0 wild-type plants and mlo2-6, agg1-1, and agg 1-1 mlo2-6 mutants following $G$. orontii challenge at $48 \mathrm{hpi}$. Regardless of the genotype, free and total SA concentrations were elevated to similar levels in response to the pathogen (Fig. 3B). In summary, these data indicate that the $\mathrm{G} \gamma 1$ subunit is dispensable for $G$. orontii-triggered SA accumulation but has a specific function in mlo2-mediated developmental SA accumulation.
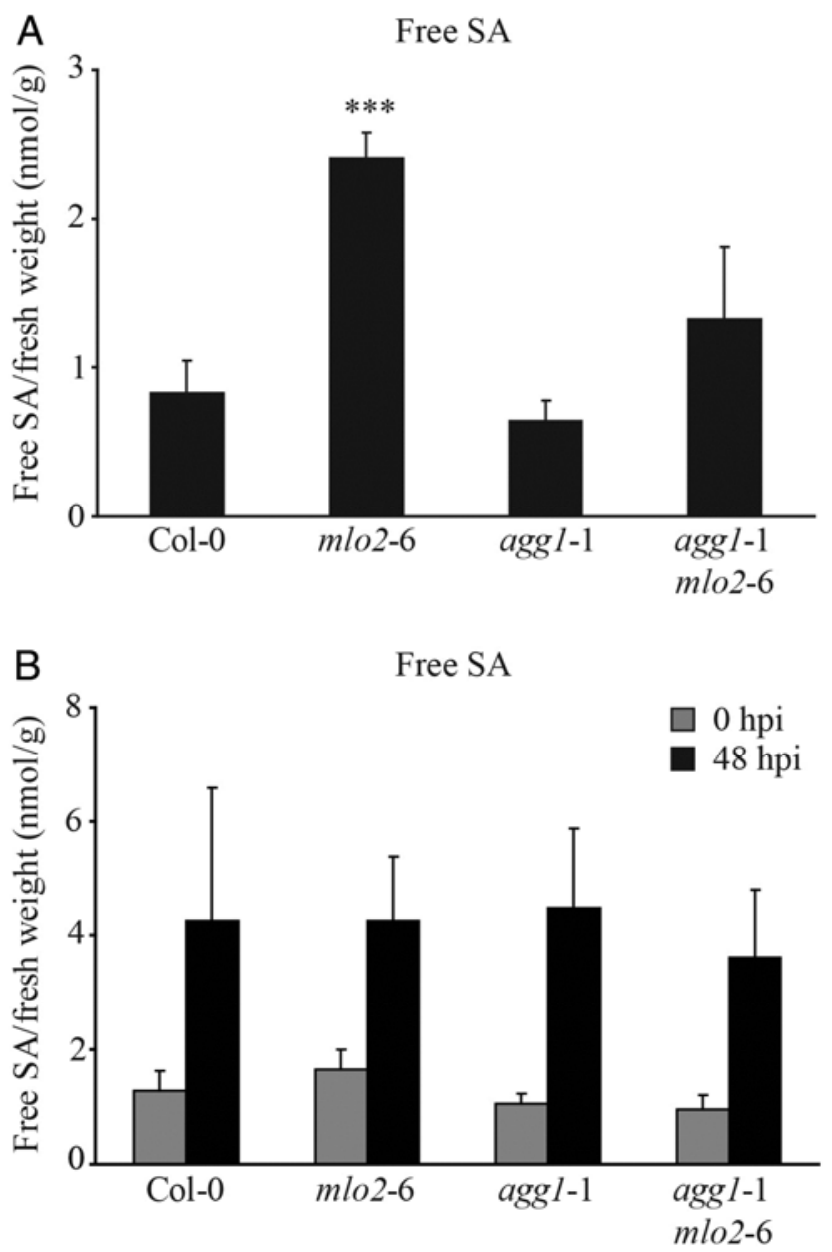

G $\beta$-deficient mutants display reduced flg22-triggered immune responses.

The presumed role of $A G B 1$ as a peripheral part of the defense regulon prompted us to take a broader look at immune responses in the $a g b l$ mutant. A previous study demonstrated a role for Arabidopsis AGB1 in microbe-associated molecular pattern (MAMP)-induced oxidative burst control (Ishikawa 2009). However, in this work, only a single AGB1 mutant allele was tested and no complementation line was analyzed. Using two independent $a g b 1$ mutants (agbl-2 and $a g b 1-9)$, we confirmed reduced reactive oxygen species (ROS) production in response to flg22 treatment in these mutants, while ROS production was slightly but not statistically significantly reduced in mutants of other G-protein components (Fig. 4).

To elucidate a potential role of the G $\beta$ subunit in MAMPmediated transcriptional activation of defense genes, we studied transcript accumulation of the known MAMP-induced genes NHL10, PHI1, PROPEP2, PROPEP3, and WRKY22 over time after flg22 treatment using quantitative reverse-transcriptase polymerase chain reaction (RT-PCR) (Boudsocq et al. 2010; Huffaker et al. 2006; Kwaaitaal et al. 2011; Lu et al. 2009b). In Col-0 wild-type plants, NHL10, PROPEP2, and $P R O P E P 3$ transcript levels gradually increased within $1 \mathrm{~h}$ after flg22 application (Fig. 5). Flg22-induced transcript accumulation of these genes was markedly reduced in both agbl mutants (agbl-2 and agbl-9), with a pronounced reduction in NHL1O and PROPEP3 expression levels and a minor decrease
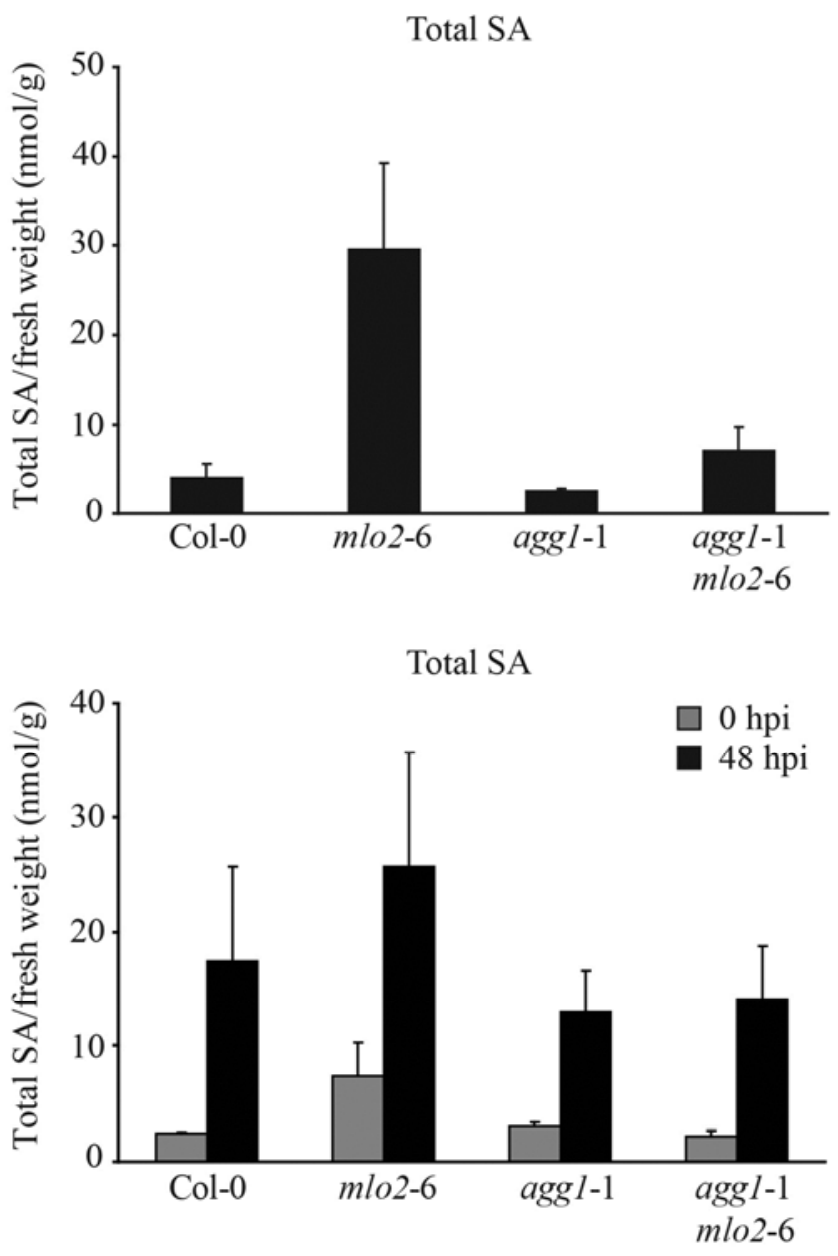

Fig. 3. Accumulation of free and total salicylic acid (SA) in wild-type, mlo2-6, agg1-1, and agg1-1 mlo2-6 mutant plants. A, SA levels were determined in rosette leaves of 6-week-old plants grown under pathogen-free conditions. B, SA concentrations were measured in rosette leaves of 4-week-old plants at $48 \mathrm{~h}$ postinoculation with Golovinomyces orontii. Results represent means \pm standard error of the mean of at least three independent experiments. Asterisks indicate a statistically significant difference from Col- 0 (*** $=P \leq 0.01$, Student's $t$ test) 
in PROPEP2 transcript accumulation compared with the wild type (Fig. 5). Although the kinetics of flg22-induced defense gene activation and the extent of its reduction in agbl mutant seedlings were subject to experimental variation, the expression level of these three genes was consistently decreased at 30 min after flg22 treatment in both agbl mutant lines throughout multiple independent experiments (Table 2). Notably, WRKY22 and PHII transcript accumulation in response to flg22 was not altered in $a g b 1$ mutant plants compared with the wild type (Supplementary Fig. S1). Together, these data suggest a function of the G $\beta$ subunit in flg22-mediated transcriptional reprogramming of a subset of Arabidopsis defense genes, including
NHL10, PROPEP2, and PROPEP3. However, AGB1 seems dispensable for the expression of other flg22-induced defense genes such as WRKY22 and PHII.

\section{Gß-deficient mutants exhibit enhanced susceptibility to the virulent bacterial pathogen \\ Pseudomonas syringae pv. tomato DC3000.}

Given that $\mathrm{G} \beta$ function is required for full expression of a subset of flg22-induced defense responses, we reasoned that agbl mutants may be compromised in antibacterial defense. Previous studies did not reveal evidence for a role of the G $\beta$ subunit in bacterial growth restriction (Ishikawa 2009; Trusov
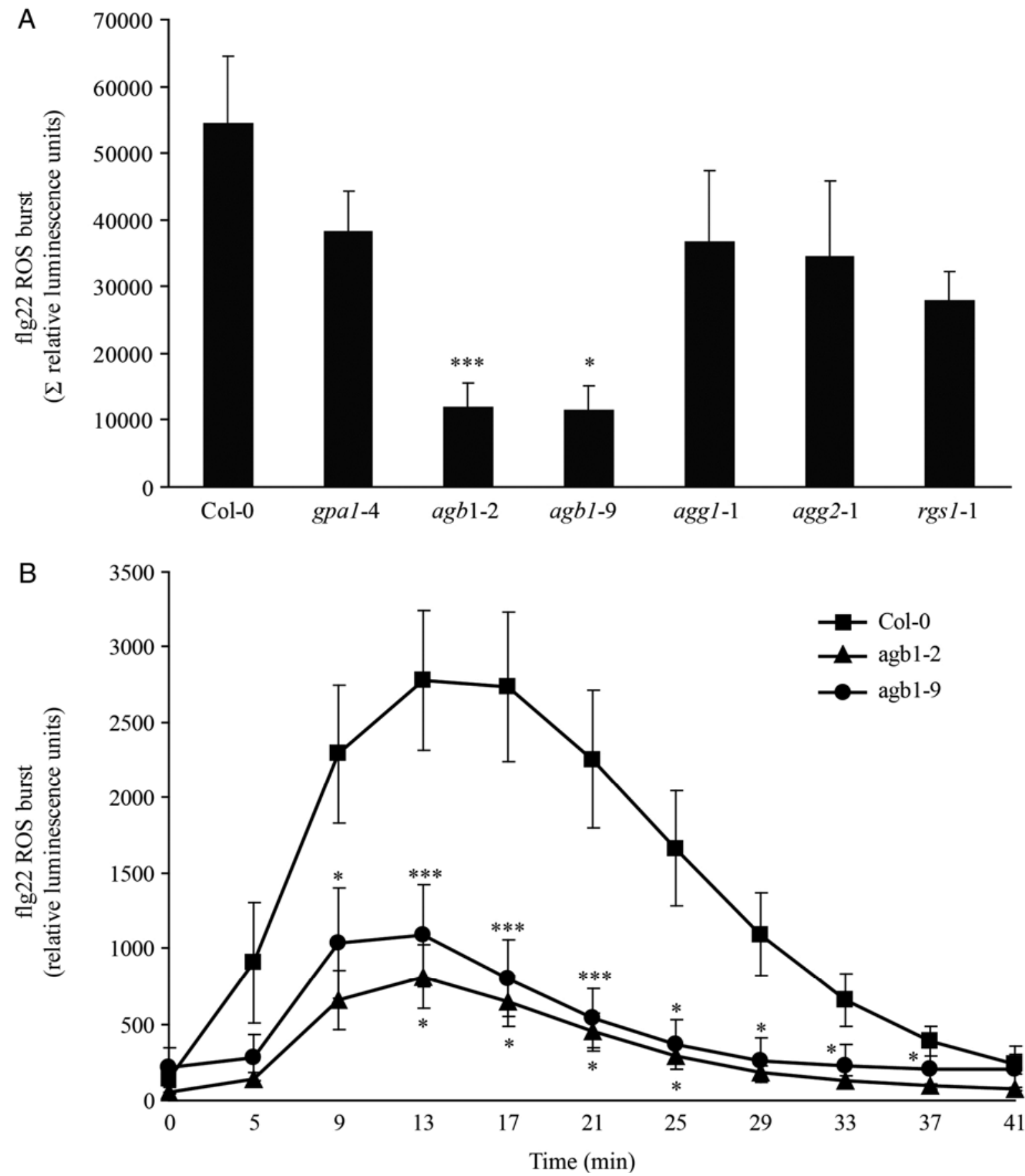

Fig. 4. Flg22-induced reactive oxygen species (ROS) burst in G-protein single mutants. Leaf discs from 4 -week-old plants were treated with $1 \mu \mathrm{M}$ flg22 and ROS formation was measured in a chemiluminescence assay. A, Flg22-induced ROS production in the indicated genotypes is represented as the integrated area under the ROS curve measured during a time course of $41 \mathrm{~min}$ and is referred to as $\Sigma$ relative luminescence units. B, ROS burst in the indicated genotypes was measured for the indicated time points after flg22 application. Results are presented as mean \pm standard error of the mean of at least five independent experiments. Asterisks indicate a significant difference from Col- 0 wild-type (*** and $*=P \leq 0.01$ and 0.05 , respectively; Student's $t$ test). 
et al. 2006) but these relied on experiments that were based on an inoculation method (syringe infiltration of bacterial cultures) that bypasses the first step of the genuine bacterial infection process. In nature, bacteria enter host plant leaves through wounds and openings such as stomata. In order to mimic the natural infection conditions, we performed bacteria spray inoculation on 4-week-old $a g b 1$ mutant plants using the Pseudomonas syringae pv. tomato DC3000 wild-type strain. At 3 days after spray inoculation with $P$. syringae pv. tomato DC3000, we observed a tendency toward enhanced macroscopic disease symptoms on the $a g b 1$ mutants $a g b 1-2$ and $a g b 1-9$ (Fig. 6A). Quantification of bacterial growth revealed a statistically sig-

A

NHL10

高

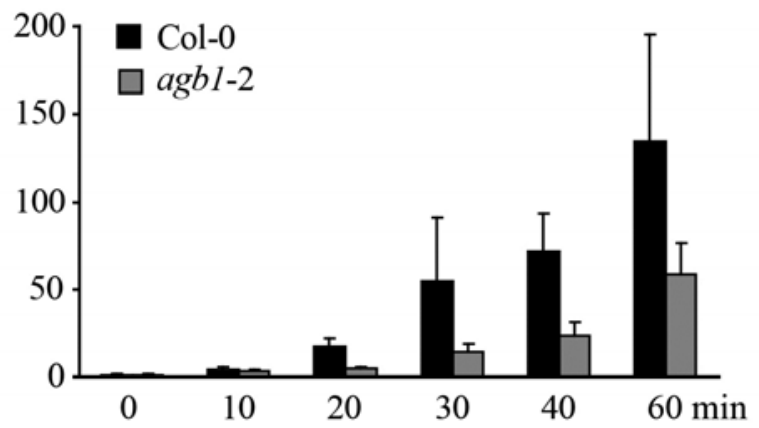

Time after flg22 treatment

C

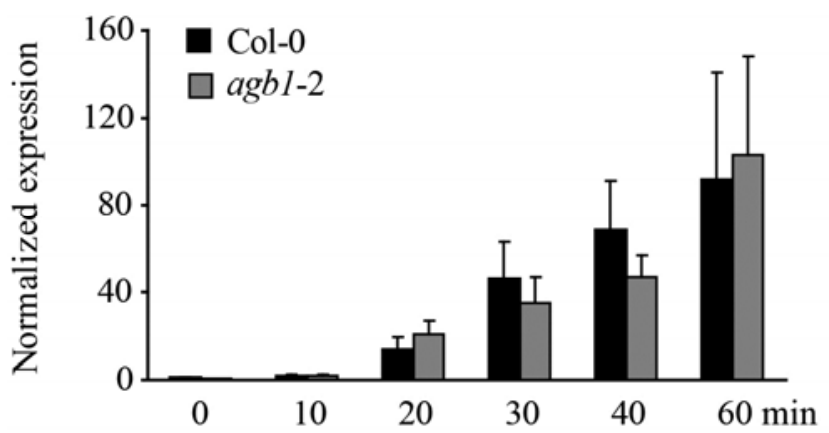

Time after flg22 treatment

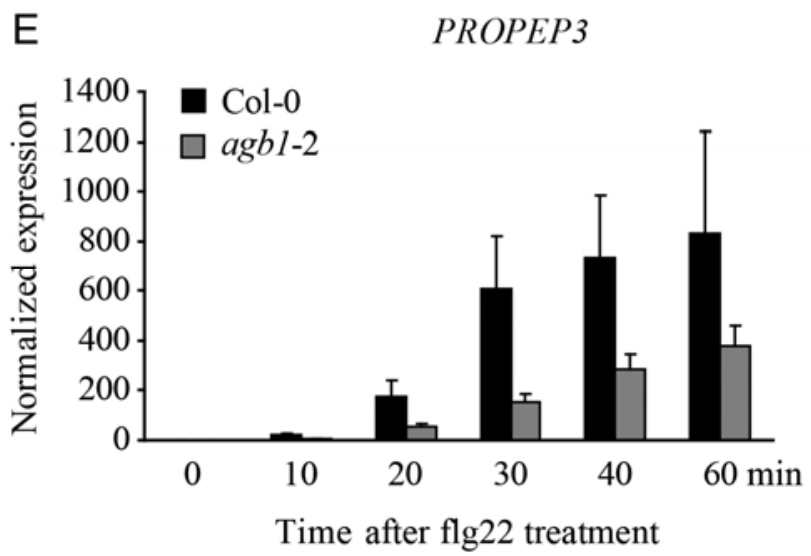

nificant increase in bacterial titers by approximately one logarithmic unit in both $a g b 1$ mutants (Fig. 6B).

\section{DISCUSSION}

The MLO2 protein is not a GPCR

in defense and callose deposition.

In the canonical model of heterotrimeric G-protein signaling, extracellular ligand binding to the GPCR induces activation of the intracellularly associated $\mathrm{G} \alpha$ subunit, resulting in the dissociation of $\mathrm{G} \alpha$ from the $\mathrm{G} \beta \gamma$ dimer and subsequent downstream signaling (Oldham and Hamm 2008). If we

B

NHL10

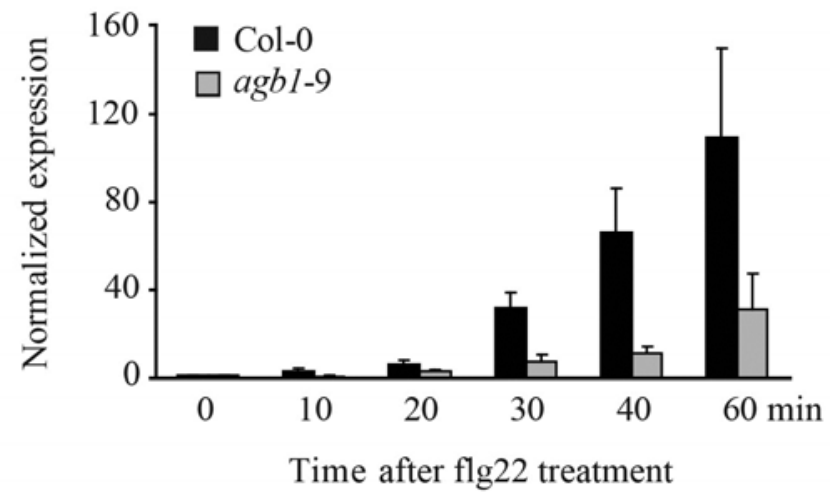

D PROPEP2

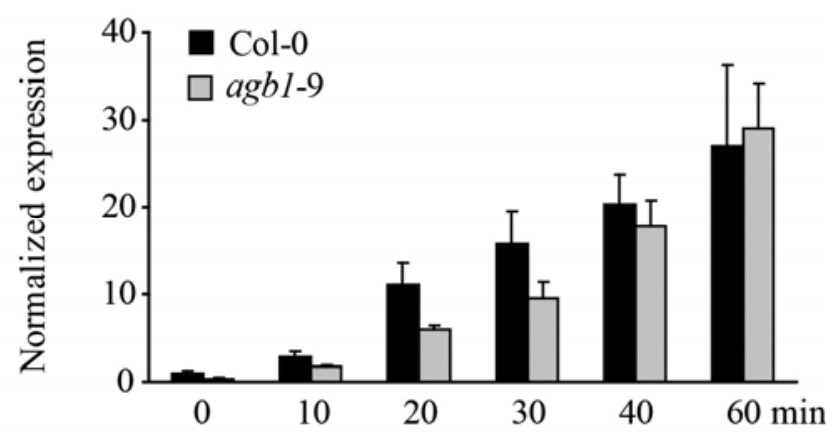

Time after flg22 treatment

$\mathrm{F}$

PROPEP3

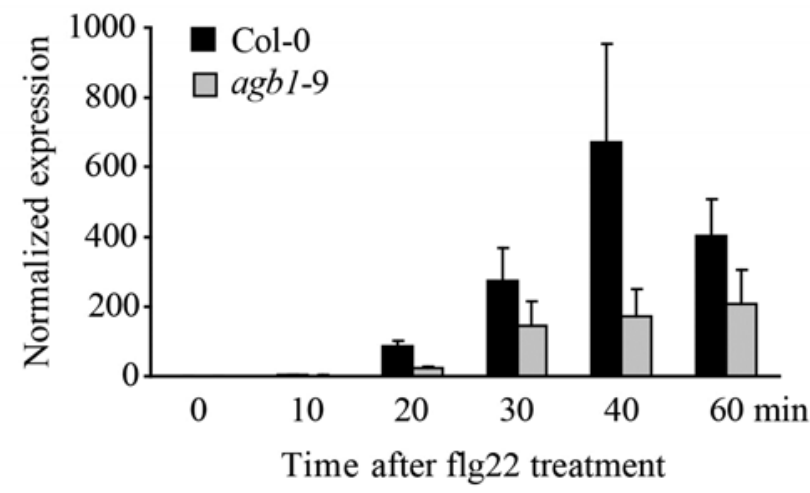

Fig. 5. Transcript levels of the microbe-activated molecular pattern-induced genes $N H L 10, P R O P E P 2$, and $P R O P E P 3$ are reduced in agb1 mutants after flg22 treatment. Two-week-old $\mathbf{A}, \mathbf{C}$, and $\mathbf{E}$, agbl-2 and $\mathbf{B}, \mathbf{D}$, and $\mathbf{F}$, agb1-9 seedlings were treated with $1 \mu \mathrm{M}$ flg22 and sampled at the indicated time points after flg22 application. Transcript levels were determined by quantitative reverse-transcriptase polymerase chain reaction. $\mathbf{A}$ and $\mathbf{B}$, NHL10; $\mathbf{C}$ and $\mathbf{D}$, PROPEP2; and E and F, PROPEP3 gene expression was normalized to the transcript levels of the reference gene At4g26420 (encoding a S-adenosylmethionine-dependent methyltransferase) and is presented relative to the transcript abundance of nontreated Col-0 wild-type at time point 0 min. A representative data set with mean \pm standard deviation of three technical replicates per genotype and time point is shown. The experiment was performed three times with similar results. 
assumed that the MLO2 protein acts as a canonical plant GPCR, we would expect Arabidopsis mutants defective in the $\mathrm{G} \alpha, \mathrm{G} \beta$, or $\mathrm{G} \gamma$ subunit to phenocopy the MLO2-deficient plants, resulting in powdery mildew resistance. However, none of the Arabidopsis mutants lacking any of the known heterotrimeric G-protein components displayed a resistant powdery mildew infection phenotype similar to mlo2 plants (Fig. 1A and B). Instead, we observed that G $\beta$ - and $\mathrm{G} \gamma$-deficient mutants exhibited enhanced powdery mildew susceptibility, indicating an involvement of these G-protein components in defense against powdery mildew fungi (Fig. 1). Although elevated fungal entry rates on $a g b l$ mutants occurred regardless of the presence or absence of the MLO2 protein, enhanced invasiveness of the pathogens on agg mutants was dependent on loss of MLO2 function (Fig. 1A and B). These findings suggest a role of $\mathrm{G} \beta$ in powdery mildew defense that is independent of MLO2, whereas the contribution of the G $\gamma$ subunits to powdery mildew immunity seems to be controlled by the MLO2 protein (discussed below, Fig. 7). We used mlo2-conditioned spontaneous callose deposition as a second, pathogen-independent readout of MLO2 function, which revealed, with the exception of the mlo2-6 agg 1-1 double mutant (discussed further below), unaltered phenotypes in the G-protein single mutants and respective double mutants in combination with mlo2-6
(Fig. 2A). In sum, none of the observed phenotypes of the Gprotein mutants is in agreement with a putative canonical Gprotein coupling function for MLO2. This is consistent with results obtained in the context of two other Arabidopsis MLO family members, MLO4 and MLO11. These MLO proteins cofunction to control root thigmomorphogenesis, and it was recently found that MLO4 and MLO11 are unlikely to operate through heterotrimeric G-proteins in this process (Chen et al. 2009).

Although results obtained in this and previous studies (Chen et al. 2009; Kim et al. 2002) disagree with a GPCR function for MLO2 in powdery mildew pathogenesis, premature leaf senescence, and root thigmomorphogenesis, this activity remains a formal possibility for other as-yet-unknown MLO-dependent processes. Alternatively, MLO proteins may constitute heptahelical cell surface receptors that transmit extracellular signals through mechanisms that function independently of G-protein coupling (also known as signaling "at zero G"), as has been proven for some GPCR in Dictyostelium discoideum and mammalian cells (Brzostowski and Kimmel 2001). Precedence in plants for such a scenario is provided by the putative Arabidopsis GPCR, GCR1, which shares notable sequence similarity (approximately $25 \%$ identity and approximately $41 \%$ similarity) to the $D$. discoideum CAR1 receptor and has been shown to act in

Table 2. Transcript levels of the mitogen-associated molecular pattern-induced genes NHL10, PROPEP2, and PROPEP3 are reduced in agb1 mutants at 30 min after flg22 treatment in multiple experiments ${ }^{\mathrm{a}}$

\begin{tabular}{|c|c|c|c|c|c|c|}
\hline \multirow[b]{2}{*}{ Experiment } & \multicolumn{3}{|c|}{ Fold change $a g b 1-2 / \mathrm{Col}-0$ at $30 \mathrm{~min}$ after flg22 treatment } & \multicolumn{3}{|c|}{ Fold change $a g b 1-9 / \mathrm{Col}-0$ at $30 \mathrm{~min}$ after flg22 treatment } \\
\hline & NHL10 & PROPEP2 & PROPEP3 & NHL10 & PROPEP2 & PROPEP3 \\
\hline 1 & 0.26 & 0.22 & 0.27 & 0.1 & 0.44 & 0.22 \\
\hline 2 & 0.28 & 0.56 & 0.36 & 0.24 & 0.32 & 0.53 \\
\hline 3 & 0.46 & 0.76 & 0.97 & 0.55 & 0.72 & 0.53 \\
\hline 4 & 0.63 & 1.16 & 0.76 & 0.61 & 0.6 & 0.67 \\
\hline 5 & 0.71 & 0.78 & & 0.65 & 0.76 & \\
\hline Mean \pm SEM $^{\mathrm{b}}$ & $0.47 \pm 0.09$ & $0.7 \pm 0.15$ & $0.59 \pm 0.17$ & $0.43 \pm 0.11$ & $0.57 \pm 0.08$ & $0.49 \pm 0.1$ \\
\hline
\end{tabular}

${ }^{a}$ Expression levels were determined by quantitative reverse-transcriptase polymerase chain reaction. Ellipses (...) indicate missing data sets.

${ }^{\mathrm{b}} \mathrm{SEM}=$ standard error of the mean.
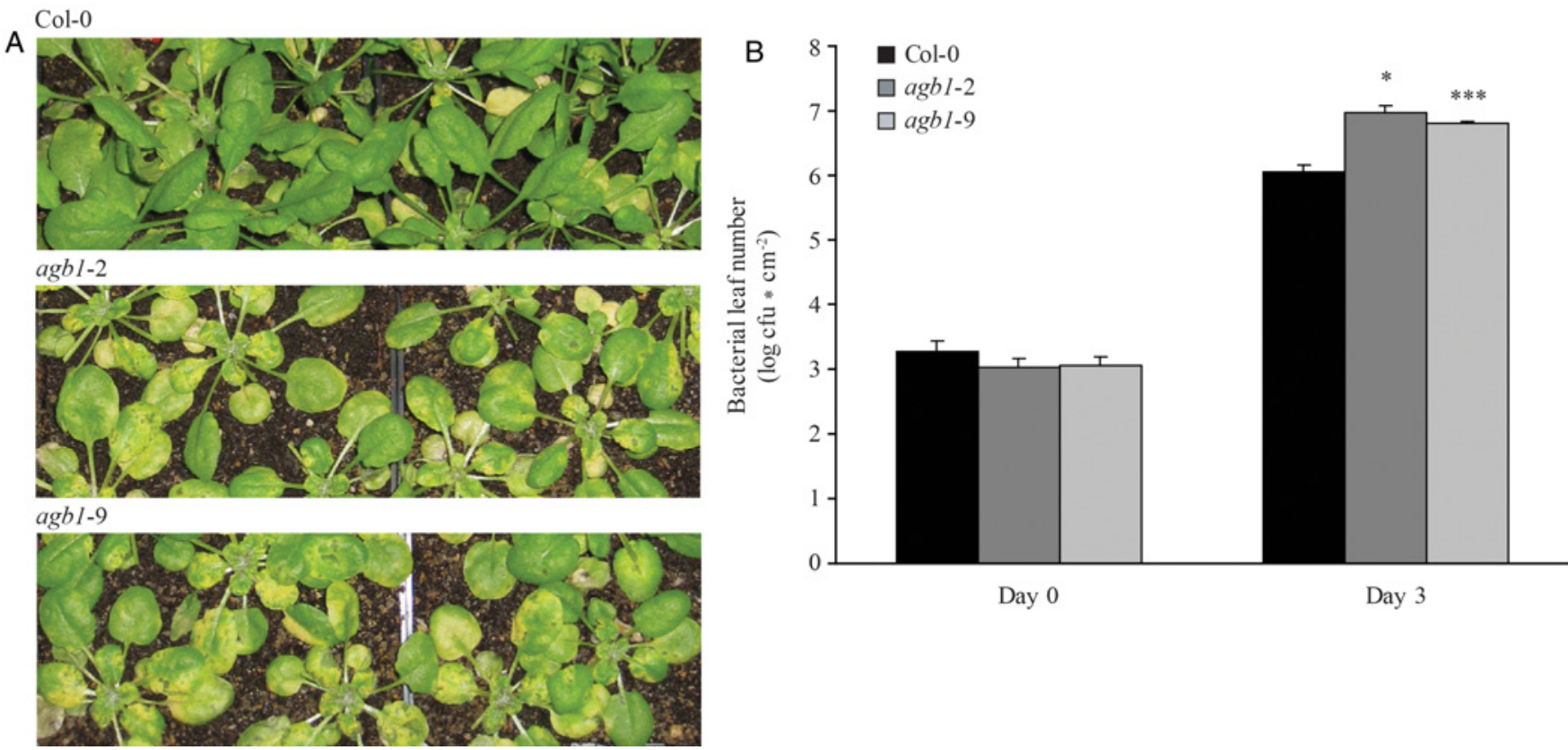

Fig. 6. Plants carrying agbl mutations are more susceptible to Pseudomonas syringae pv. tomato DC 3000 bacteria. Four-week-old plants were sprayed with $P$. syringae pv. tomato DC3000 bacteria at an optical density at $600 \mathrm{~nm}$ of 0.2 . A, Macroscopic disease symptoms of the indicated genotypes 3 days after $P$. syringae pv. tomato DC3000 inoculation. B, P. syringae pv. tomato DC3000 bacterial titers were determined at $3 \mathrm{~h}(=$ day 0$)$ and 3 days after inoculation. Results are presented as mean \pm standard error of the mean of four independent experiments. Asterisks indicate a significant difference from the Col- 0 wild type (*** and $*=P \leq 0.01$ and 0.05 , respectively; Student's $t$ test). 
both G-protein-dependent and -independent pathways (Chen et al. 2004; Pandey and Assmann 2004). However, kinetic studies demonstrated that the sole canonical Arabidopsis $\mathrm{G} \alpha$ subunit is in the activated GTP-bound state by default, suggesting that the heterotrimeric G-protein acts without cognate GPCR in Arabidopsis signaling (Johnston et al. 2007; Jones et al. 2011; Urano and Jones 2013; Urano et al. 2012).

It is also conceivable that the function of MLO proteins is entirely unrelated to ligand binding but may involve transduction of signals perceived by other types of receptors or may serve a nonreceptor function. The Arabidopsis genome contains more than 600 receptor-like kinases (RLKs), which represent nearly $2.5 \%$ of the annotated protein-coding genes (Shiu and Bleecker 2001). Results from a recent study aiming at the elucidation of the Arabidopsis membrane interactome by applying the yeast split-ubiquitin technology suggest that some MLO proteins interact with RLKs (Lalonde et al. 2010). In agreement with a presumptive function of MLO proteins in RLKassociated processes, MLO7/NORTIA, another member of the Arabidopsis MLO protein family, and FERONIA (FER), an RLK, both control pollen tube reception (Kessler et al. 2010). Moreover, fer and mlo7 as well as mlo2 mutants share several phenotypic similarities, suggesting that FER and various MLO proteins co-function to regulate pollen tube reception, powdery mildew pathogenesis, and perhaps other, as-yet-unknown processes. However, a direct physical interaction between MLO proteins and FER has not been found as yet (S. Kessler and U. Grossniklaus, personal communication).

\section{The G $\beta$ subunit acts in defense against microbes with various pathogenic lifestyles.}

A number of early pharmacological analyses originally suggested a role for the heterotrimeric G-protein in plant defense (Beffa et al. 1995; Gelli et al. 1997; Han and Yuan 2004; Legendre et al. 1992; Mahady et al. 1998; Rajasekhar et al. 1999; Vera-Estrella et al. 1994). Meanwhile, genetic studies with Arabidopsis G-protein mutants provided conclusive evidence for a function of heterotrimeric G-protein signaling in plant immunity. Arabidopsis mutants lacking AGB1 display increased susceptibility to the necrotrophic fungi Plectosphaerella cucumerina, Alternaria brassicicola, Fusarium oxysporum, and Botrytis cinerea, indicating a role for G $\beta$ in defense against these pathogens (Llorente et al. 2005; Trusov et al. 2006, 2007). In contrast, previous analyses failed to support an involvement of $\mathrm{G} \beta$ in defense against pathogens with a (hemi-)biotrophic lifestyle such as Pseudomonas syringae bacteria or the oomycete Hyaloperonospora arabdopsidis (Llorente et al. 2005; Trusov et al. 2006).

In the present study, we found that Arabidopsis G $\beta$-deficient mutants allow higher host cell entry by the biotrophic powdery mildew fungi $G$. orontii and $E$. pisi, indicating a role for $\mathrm{G} \beta$ in preinvasive defense against adapted and nonadapted species of these obligate biotrophic pathogens (Fig. 1A and B). The macroscopically visible powdery mildew disease symptoms on $a g b$ mlo2-6 double-mutant plants (Fig. 1C) indicate copious growth of fungal hyphae and conidiophores, suggesting an additional role of the $\mathrm{G} \beta$ subunit in postinvasive defense against $G$. orontii. Moreover, upon inoculation of $P$. syringae via spray inoculation, a procedure that more closely resembles the conditions of natural bacterial infection, we also observed increased bacterial susceptibility on G $\beta$-deficient mutants, pointing to an additional role of $\mathrm{G} \beta$ in bacterial growth restriction (Fig. 6). Thus, data acquired in this study support a function of the G $\beta$ subunit in Arabidopsis defense against pathogens with a (hemi-)biotrophic lifestyle (Fig. 7). Our findings are in line with two recently published studies, which likewise revealed enhanced disease susceptibility of the G $\beta$-deficient agbl-2 mutant following spray inoculation with virulent ( $P$. syringae), avirulent ( $P$. syringae avrRpml or avrRpt2), or disabled $(P$. syringae mutant deficient in coronatine biosynthesis) bacterial pathogens (Liu et al. 2013; Torres et al. 2013). They are further consistent with the previous notion that the Arabidopsis G $\beta$ subunit contributes to defense against the nonadapted fungal pathogen Magnaporthe oryzae (Maeda et al. 2009), whereas $\mathrm{G} \beta$ seems dispensable for immunity to nonadapted isolates of P. cucumerina (Sanchez Vallet et al. 2010).

Given that G $\beta$-dependent processes contribute to defense against a broad spectrum of plant pathogens with various parasitic lifestyles, G $\beta$ likely either plays a role in basal plant immune mechanisms or indirectly affects plant immunity. Although coexpression data favor the first possibility (Table 1), recent publications revealed a novel function for $G \beta$ in the regulation of cell wall architecture, which may support the second scenario (Delgado-Cerezo et al. 2012; Klopffleisch et al. 2011). It is well established that alterations in Arabidopsis cell wall composition can lead to modified immune responses to various plant pathogens (Cantu et al. 2008 ; Ellis and Turner 2001; Hernández-Blanco et al. 2007; Vogel et al. 2002, 2004). Therefore, loss of G $\beta$-regulated cell wall modifications may be the cause for the altered plant disease responses. Moreover, it was previously reported that agbl mutants exhibit increased stomatal density (Zhang et al. 2008). Elevated numbers of stomata may also explain the enhanced bacterial titers of $P$. syringae bacteria in G $\beta$-deficient mutants after bacteria spray inoculation (Fig. 6), which was not observed as a result of syringe infiltration of bacterial cultures (Ishikawa 2009; Liu et al. 2013; Trusov et al. 2006). However, this morphological phenotype cannot account for the heightened entry levels of powdery mildew fungi (Fig. 1A and B) because these directly penetrate epidermal pavement cells.

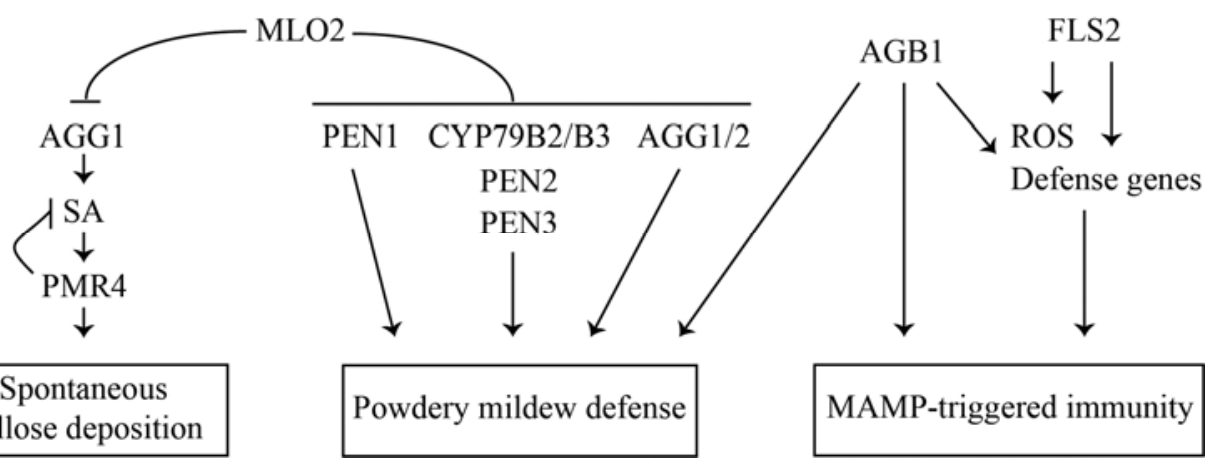

Fig. 7. Proposed model for the involvement of the heterotrimeric G-protein complex in powdery mildew defense, in microbe-activated molecular patterntriggered immunity and in MLO2-mediated control of spontaneous callose deposition. The model integrates previous findings (Consonni et al. 2006, 2010) and data obtained in this study. 
The $\mathbf{G} \gamma$ subunits are required

for mlo2-mediated powdery mildew resistance.

Arabidopsis mlo2-based powdery mildew resistance relies on functional SNARE protein-dependent secretory defense and the biosynthesis and extrusion of indolic secondary metabolites, because mutations in components of these two independent defense pathways compromise powdery mildew immunity in the mlo2 mutant background (Consonni et al. 2006, 2010). Similarly, mlo2-mediated penetration resistance to the powdery mildew fungi $G$. orontii and $E$. pisi was compromised by mutations in the G $\gamma$ subunits AGG1 and AGG2, indicating that $\mathrm{G} \gamma$ functions are also required for $m l o 2$-mediated powdery mildew resistance (Figs. 1A and B and 7). Notably, mlo2 resistance against $G$. orontii was only compromised when both $A G G 1$ and $A G G 2$ were disrupted, indicating that both $\mathrm{G} \gamma$ subunits have complementary functions in defense against the adapted powdery mildew pathogen (Fig. 1A). Redundant functions for these two $G \gamma$ subunits were recently also described in immunity against nonpathogenic or disabled bacterial pathogens (Liu et al. 2013). Compared with the previously described suppressors of mlo2 resistance (Consonni et al. 2006, 2010), we found that elevated $G$. orontii entry rates in the agbl mlo2-6 double mutants and agg 1-1 agg2-1 mlo2-6 triple mutant were intermediate between Col- 0 wild-type and mlo 2 control plants, indicating a less pronounced role for the $G \beta$ and $G \gamma$ subunits in defense against the compatible powdery mildew fungus.

Although the G $\beta$ subunit seems to contribute to both preand postinvasive defense to $G$. orontii, the effect of the two $G \gamma$ subunits appears to be restricted to preinvasive defense, because the agg 1-1 agg2-1 mlo2-6 triple mutant retained the macroscopic resistance phenotype of the mlo2-6 single mutant (Fig. 1C). However, it is also possible that an additional mutation in the recently discovered $A G G 3$ gene (Chakravorty et al. 2011) is required to fully phenocopy the $a g b l$ mutant. Precedence for such a scenario is provided by several morphological phenotypes of the $a g b l$ mutant, such as rosette leaf shape and flower and silique length, which are fully phenocopied only by the aggl aag2 agg3 triple mutant (Thung et al. 2012).

In contrast to results obtained with $G$. orontii, mlo2-mediated resistance against the pea powdery mildew fungus, E. pisi, was already impaired in the absence of the $G \gamma 1$ subunit (Fig. 1B). This finding indicates that defense against the nonadapted pathogen in the mlo2 genotype is selectively mediated by $\mathrm{G} \gamma 1$, whereas the $\mathrm{G} \gamma 2$ subunit seems to be dispensable in this context. Unlike the previously identified suppressors of mlo2 resistance, mutations in $A G G 1$ (or $A G G 2$ ) do not affect resistance against $E$. pisi in the presence of $M L O 2$ (Fig. 1B), suggesting that AGG1 and AGG2 operate in a pathway that is unrelated to SNARE protein-mediated secretion and indolic secondary metabolite biosynthesis. Regardless of the underlying mechanism, these data indicate differential requirements of $\mathrm{G} \gamma 1$ and $\mathrm{G} \gamma 2$ in mlo2-mediated defense against adapted and nonadapted powdery mildew fungi. Selective functionality of the $\mathrm{G} \gamma$ subunits was previously described in defense against the necrotrophic fungus A. brassicicola (Trusov et al. 2007).

\section{The G $\beta$ subunit mediates \\ flg22-triggered immune responses.}

Perception of MAMPs by the corresponding pattern recognition receptorsis associated with the activation of diverse physiological responses that are thought to contribute to robust immunity. However, mechanisms by which MAMP-induced responses are achieved are largely unknown. Increasing evidence points to a role of heterotrimeric G-protein signaling in the integration of MAMP perception into downstream responses (Ishikawa 2009; Liu et al. 2013; Torres et al. 2013; Zhang et al. 2008, 2011). A previous study revealed a role for
AGB1 in MAMP-induced oxidative burst control, positioning G $\beta$-mediated signaling early after MAMP perception upstream of respiratory burst oxidase homolog $\mathrm{D}$ (RbohD) activity, the NADPH oxidase essential for MAMP-induced ROS production (Ishikawa 2009; Zhang et al. 2007). Using two independent $a g b 1$ mutants (agbl-2 and agbl-9), we corroborated reduced ROS production in response to flg22 treatment in these mutants (Fig. 4). Residual ROS spiking in agbl mutants suggests the involvement of additional components in flg22-triggered oxidative burst control. Detailed analysis of the interplay between the NADPH oxidases RbohD/RbohF and AGB1 recently revealed that $a g b 1$ null mutants are epistatic to the NAPDH oxidase null alleles (Torres et al. 2013).

Although flg22-induced ROS production was reduced in G $\beta$ deficient mutants, the MAMP-triggered activation of mitogenactivated protein kinase (MAPK) cascades was not affected, indicating that $G \beta$-dependent signaling is not required for MAPK activity (Ishikawa 2009; Liu et al. 2013). Together, these results suggest that either both events occur independently of each other or that MAPKs act upstream of G $\beta$-mediated ROS formation. The relationship between ROS and MAPK cascades in plant defense is controversial; whereas some results favor the action of MAPKs upstream of ROS formation (Zhang et al. 2007), other data contradict this hypothesis (Boudsocq et al. 2010; Lu et al. 2009b).

Data obtained in this study support a role for G $\beta$ in flg22mediated transcriptional reprogramming. Interestingly, G $\beta$ seems to regulate the transcript accumulation of a subset of defense marker genes (NHL10, PROPEP2, and PROEP3), whereas it does not affect the expression of other defenserelated genes (WRKY22, PHI1, FRK1, GST1, and WRKY29) (Fig. 5) (Liu et al. 2013). These findings indicate the existence of $\mathrm{G} \beta$-dependent and $\mathrm{G} \beta$-independent pathways regulating transcriptional reprogramming in response to MAMP treatment. This concept is in agreement with the recently proposed model of MAPK- and calcium-dependent protein kinase-specific activation of MAMP-triggered defense gene expression (Boudsocq et al. 2010).

Although our experiments focused on the bacterial MAMP flg22, Liu and associates (2013) found that agbl mutants are not only compromised in MAMP-induced resistance to bacterial infection triggered by flg22 but also insensitive to MAMPinduced resistance induced by the bacterial MAMP elf18 and the fungal MAMP chitin. These results suggest that AGB1 plays a role in the response pathways to multiple MAMPs, including chitin. The latter provides a plausible explanation for the compromised defense response of agbl mutants upon challenge with fungal pathogens (Fig. 1) (Llorente et al. 2005; Trusov et al. 2006, 2007).

In summary, results from this and previous studies demonstrate that, despite the simple repertoire of heterotrimeric Gprotein components found in plants, signaling processes using the heterotrimeric G-protein are highly complex.

\section{MATERIALS AND METHODS}

\section{Plant material and growth conditions.}

Arabidopsis thaliana wild-type Col-0, agb1-2 (mutant) (Ullah et al. 2003), agg1-1 (Trusov et al. 2007), agg2-1 (Trusov et al. 2007), agg1-1/agg2-1 (Trusov et al. 2007), gpal-4 (Jones et al. 2003), mlo2-6 (Consonni et al. 2006), agbl-9 (GalvezValdivieso et al. 2009), and rgsl-1 (Chen et al. 2003) mutants were described. With the exception of agbl-9, which is an EMS allele leading to a premature stop codon in the $A G B 1$ coding sequence, the mutants are T-DNA insertion lines lacking any transcript. All plant lines except agg 1-1 are in the Col-0 background. The agg 1-1 line originates from the Arabidopsis acces- 
sion Ws-0 and was subsequently introgressed into the Col-0 ecotype by eight backcrosses (Trusov et al. 2007). The Ws-0 accession carries a natural mutation in the gene encoding the flagellin receptor FLS2 and, therefore, is insensitive to flg22 treatment (Gómez-Gómez and Boller 2000). Sequencing of the FLS2 gene in the agg1-1 agg2-1 double mutant revealed the presence of the natural fls 2 mutation in the double mutant but not in the backcrossed agg 1-1 single mutant (data not shown). Therefore, we excluded the agg1-1 agg2-1 double mutant from the analysis of flg22-triggered effects.

G-protein $m l o 2$ double and triple mutants were generated by crossing mlo2-6 plants with the corresponding G-protein mutants. Homozygous insertion mutants were selected by PCR using T-DNA- and gene-specific primer sets as described on the T-DNA Express webpage. Primer sequences are available on request. Homozygous agbl-9 mutants were identified by cleaved amplified polymorphic sequence (dCAPS) analysis using the dCAPS markers 5'-GCTATGCGAGCAACAACACT TGCTACGCTT-3' and 5'-CTGACAACCCCAAACAGC-TT-3' followed by a $D d e I$ digestion.

For flg22-triggered gene expression assays, seedlings were pregrown on one-half Murashige Skoog agar plates with $0.25 \%$ sucrose for 5 days and, subsequently, on analogous liquid medium for additional 5 to 7 days under a cycle of 10 and $14 \mathrm{~h}$ of light and darkness, respectively, at $21^{\circ} \mathrm{C}$ and $70 \%$ relative humidity. For all other experiments, plants were soil grown under controlled conditions under a cycle of 10 and $14 \mathrm{~h}$ of light and darkness, respectively at $23^{\circ} \mathrm{C}$ and $65 \%$ relative humidity.

\section{Phytopathogens and infection assays.}

The powdery mildew isolates of G. orontii and E. pisi kept at the Max-Planck Institute for Plant Breeding Research were used in this study (Lipka et al. 2005) and powdery mildew infection assays were performed as described previously (Consonni et al. 2006). The bacterial strain used was $P$. syringae pv. tomato DC3000 and bacteria spray infection assays were conducted as described before (Heidrich et al. 2011).

\section{Analysis of callose deposition.}

For visualization of callose, rosette leaves were detached, cleared with ethanol/acetic acid (3:1 [ $\mathrm{vol} / \mathrm{vol}])$, and subsequently stained for $24 \mathrm{~h}$ with $0.01 \%$ aniline blue in $150 \mathrm{mM} \mathrm{KH}_{2} \mathrm{PO}_{4}$ ( $\mathrm{pH}$ 5.8). Callose deposits were visualized by epifluorescence microscopy using a UV filter set. For the analysis of spontaneous callose deposition, 6-week-old plants were used; for the analysis of wound-induced callose, leaves from 4-week-old plants were squeezed with forceps and collected after $24 \mathrm{~h}$. For visualization of papillary callose, 4-week-old plants were inoculated with $E$. pisi and leaves were harvested at $7 \mathrm{dpi}$.

\section{Quantification of SA.}

SA quantification was done as previously described (Straus et al. 2010).

\section{ROS analysis.}

ROS assays were performed as described (Gómez-Gómez et al. 1999) with the following modifications. Leaf discs $(5 \mathrm{~mm}$ in diameter) excised from 4-week-old plants were incubated overnight in water before they were transferred into microtiter plates containing $50 \mu \mathrm{l}$ of water. ROS production was triggered by the addition of $1 \mu \mathrm{M}$ flg22 (peptide, QRLSTGSRINSAKD DAAGLQIA; synthesized by Centic Biotec, Weimar, Germany), applied in a reaction mixture containing $50 \mu \mathrm{l}$ of water, $20 \mu \mathrm{M}$ luminol (Fluka, Steinheim, Germany) and $1 \mu \mathrm{g}$ of horseradish peroxidase (Sigma-Aldrich, Taufkirchen, Germany). Luminescence was measured in a Centro LB 960 microplate luminometer (Berthold Technologies, Bad Wildbad, Germany). Flg22- mediated ROS production (relative luminescence units) in Figure $4 \mathrm{~A}$ is represented as the integrated area under the ROS curve measured during a time course of $41 \mathrm{~min}$ and is referred to as $\Sigma$ relative luminescence units. The kinetic of flg22-mediated ROS production during a time course of $41 \mathrm{~min}$ is displayed in Figure 4B.

\section{Gene expression analysis.}

The treatment of seedlings with flg22, the extraction of total RNA, cDNA synthesis, and quantitative RT-PCR were performed essentially as described previously (Kwaaitaal et al. 2011). To quantify transcripts of the indicated genes, the following forward and reverse primers were used: $5^{\prime}$-GAGCTGAA GTGGCTTCCATGAC-3' and 5'-GGTCCGACATACCCATG ATCC-3' for At4g26420 (Czechowski et al. 2005); 5'-TTCC TGTCCGTAACCCAAAC-3' and 5'-CCCTCGTAGTAGGCA TGAGC-3' for NHL10 (At2g35980) (Boudsocq et al. 2010); 5'-TTGGTTTAGACGGGATGGTG-3' and 5'-ACTCCAGTAC AAGCCGATCC-3' for PHII (At1g35140) (Boudsocq et al. 2010); 5'-AGAAAAGCCTAGTTCAGGTCGTC-3' and 5'-C TCCTTATAAACTTGTATTGCCGC-3' for PROPEP2 (At5g64890); 5'-GTTCCGGTCTCGAAAGTTCATC-3' and 5'-TGAACTCTAATTGTGTTTGCCTCC-3' for PROPEP3 (At5g64905), and 5'-CATCCGATCAACAGACGAGTAAA T- $3^{\prime}$ and $5^{\prime}$-AAATTCGTCGGCTGAAGTCAC-3' for WRKY22 (At4g01250) (Lu et al. 2009b).

\section{ACKNOWLEDGMENTS}

We thank A. Reinstädler for technical assistance in plant genotyping and SA measurements. This work was supported by grants of the Deutsche Forschungsgemeinschaft (grant number PA861-6/1) to R. Panstruga and the Max-Planck Society post-doctoral fellowship to J. Lorek.

\section{LITERATURE CITED}

Bai, Y., Pavan, S., Zheng, Z., Zappel, N. F., Reinstädler, A., Lotti, C., De Giovanni, C., Ricciardi, L., Lindhout, P., Visser, R., Theres, K., and Panstruga, R. 2008. Naturally occurring broad-spectrum powdery mildew resistance in a central American tomato accession is caused by loss of Mlo function. Mol. Plant-Microbe Interact. 21:30-39.

Beffa, R., Szell, M., Meuwly, P., Pay, A., Vogeli-Lange, R., Metraux, J. P., Neuhaus, G., Meins, F., and Nagy, F. 1995. Cholera toxin elevates pathogen resistance and induces pathogenesis-related gene expression in tobacco. EMBO (Eur. Mol. Biol. Organ.) J. 14:5753-5761.

Boudsocq, M., Willmann, M. R., McCormack, M., Lee, H., Shan, L., He, P., Bush, J., Cheng, S.-H., and Sheen, J. 2010. Differential innate immune signalling via $\mathrm{Ca}^{2+}$ sensor protein kinases. Nature 464:418422.

Brzostowski, J. A., and Kimmel, A. R. 2001. Signaling at zero G: G-protein-independent functions for 7-TM receptors. Trends Biochem. Sci. 26:291-297.

Büschges, R., Hollricher, K., Panstruga, R., Simons, G., Wolter, M., Frijters, A., van Daelen, R., van der Lee, T., Diergaarde, P., Groenendijk, J., Töpsch, S., Vos, P., Salamini, F., and Schulze-Lefert, P. 1997. The barley Mlo gene: A novel control element of plant pathogen resistance. Cell 88:695-705.

Cantu, D., Vicente, A. R., Labavitch, J. M., Bennett, A. B., and Powell, A. L. T. 2008. Strangers in the matrix: Plant cell walls and pathogen susceptibility. Trends Plant Sci. 13:610-617

Chakravorty, D., Trusov, Y., Zhang, W., Acharya, B. R., Sheahan, M. B., McCurdy, D. W., Assmann, S. M., and Botella, J. R. 2011. An atypical heterotrimeric G-protein $\gamma$-subunit is involved in guard cell $\mathrm{K}^{+}$-channel regulation and morphological development in Arabidopsis thaliana. Plant J. 67:840-851.

Chen, J.-G. 2008. Heterotrimeric G-protein signaling in Arabidopsis: Puzzling G-protein-coupled receptor. Plant Signal. Behav. 3:1042-1045.

Chen, J. G., Willard, F. S., Huang, J., Liang, J., Chasse, S. A., Jones, A. M., and Siderovski, D. P. 2003. A seven-transmembrane RGS protein that modulates plant cell proliferation. Science 301:1728-1731.

Chen, J.-G., Pandey, S., Huang, J., Alonso, J. M., Ecker, J. R., Assmann, S. M., and Jones, A. M. 2004. GCR1 can act independently of heterotrimeric G-protein in response to brassinosteroids and gibberellins in Arabidopsis seed germination. Plant Physiol. 135:907-915. 
Chen, Z., Noir, S., Kwaaitaal, M., Hartmann, H. A., Wu, M.-J., Mudgil, Y., Sukumar, P., Muday, G., Panstruga, R., and Jones, A. M. 2009. Two seven-transmembrane domain MILDEW RESISTANCE LOCUS O proteins cofunction in Arabidopsis root thigmomorphogenesis. Plant Cell 21:1972-1991.

Consonni, C., Humphry, M. E., Hartmann, H. A., Livaja, M., Durner, J., Westphal, L., Vogel, J., Lipka, V., Kemmerling, B., Schulze-Lefert, P., Somerville, S. C., and Panstruga, R. 2006. Conserved requirement for a plant host cell protein in powdery mildew pathogenesis. Nat. Genet. 38:716-720.

Consonni, C., Bednarek, P., Humphry, M., Francocci, F., Ferrari, S., Harzen, A., Ver Loren van Themaat, E., and Panstruga, R. 2010. Tryptophanderived metabolites are required for antifungal defense in the Arabidopsis mlo2 mutant. Plant Physiol. 152:1544-1561.

Czechowski, T., Stitt, M., Altmann, T., Udvardi, M. K., and Scheible, W.R. 2005. Genome-wide identification and testing of superior reference genes for transcript normalization in Arabidopsis. Plant Physiol. 139:517.

Delgado-Cerezo, M., Sánchez-Rodríguez, C., Escudero, V., Miedes, E., Fernández, P. V., Jordá, L., Hernández-Blanco, C., Sánchez-Vallet, A., Bednarek, P., Schulze-Lefert, P., Somerville, S., Estevez, J. M., Persson, S., and Molina, A. 2012. Arabidopsis heterotrimeric G-protein regulates cell wall defense and resistance to necrotrophic fungi. Mol. Plant 5:98114

Devoto, A., Piffanelli, P., Nilsson, I., Wallin, E., Panstruga, R., von Heijne, G., and Schulze-Lefert, P. 1999. Topology, subcellular localization, and sequence diversity of the Mlo family in plants. J. Biol. Chem. 274:34993-35004.

Ellis, C., and Turner, J. G. 2001. The Arabidopsis mutant cev1 has constitutively active jasmonate and ethylene signal pathways and enhanced resistance to pathogens. Plant Cell 13:1025-1033.

Fujisawa, Y., Kato, H., and Iwasaki, Y. 2001. Structure and function of heterotrimeric $\mathrm{G}$ proteins in plants. Plant Cell Physiol. 42:789-794.

Galvez-Valdivieso, G., Fryer, M. J., Lawson, T., Slattery, K., Truman, W. Smirnoff, N., Asami, T., Davies, W. J., Jones, A. M., Baker, N. R., and Mullineaux, P. M. 2009. The high light response in Arabidopsis involves ABA signaling between vascular and bundle sheath cells. Plant Cell 21:2143-2162.

Gelli, A., Higgins, V. J., and Blumwald, E. 1997. Activation of plan plasma membrane $\mathrm{Ca}^{2+}$-permeable channels by race-specific fungal elicitors. Plant Physiol. 113:269-279.

Gómez-Gómez, L., and Boller, T. 2000. FLS2: An LRR receptor-like kinase involved in the perception of the bacterial elicitor flagellin in Arabidopsis. Mol. Cell 5:1003-1011.

Gómez-Gómez, L., Felix, G., and Boller, T. 1999. A single locus determines sensitivity to bacterial flagellin in Arabidopsis thaliana. Plant J. $18: 277-284$

Han, R.-B., and Yuan, Y.-J. 2004. Oxidative burst in suspension culture of Taxus cuspidate induced by a laminar shear stress in short-term. Biotechnol. Prog. 20:507-513.

Heidrich, K., Wirthmueller, L., Tasset, C., Pouzet, C., Deslandes, L., and Parker, J. E. 2011. Arabidopsis EDS1 connects pathogen effector recognition to cell compartment-specific immune responses. Science 334:1401-1404.

Hernández-Blanco, C., Feng, D. X., Hu, J., Sánchez-Vallet, A., Deslandes, L., Llorente, F., Berrocal-Lobo, M., Keller, H., Barlet, X., SánchezRodríguez, C., Anderson, L. K., Somerville, S., Marco, Y., and Molina, A. 2007. Impairment of cellulose synthases required for Arabidopsis secondary cell wall formation enhances disease resistance. Plant Cell 19:890-903.

Huffaker, A., Pearce, G., and Ryan, C. A. 2006. An endogenous peptide signal in Arabidopsis activates components of the innate immune response. Proc. Natl. Acad. Sci. U.S.A. 103:10098-10103.

Humphry, M., Bednarek, P., Kemmerling, B., Koh, S., Stein, M., Göbel, U., Stüber, K., Piślewska-Bednarek, M., Loraine, A., Schulze-Lefert, P., Somerville, S., and Panstruga, R. 2010. A regulon conserved in monocot and dicot plants defines a functional module in antifungal plant immunity. Proc. Natl. Acad. Sci. U.S.A. 107:21896-21901.

Humphry, M., Reinstädler, A., Ivanov, S., Bisseling, T., and Panstruga, R. 2011. Durable broad-spectrum powdery mildew resistance in pea erl plants is conferred by natural loss-of-function mutations in PSMLO1. Mol. Plant Pathol. 12:866-878.

Ishikawa, A. 2009. The Arabidopsis G-protein beta-subunit is required for defense response against Agrobacterium tumefaciens. Biosci. Biotech. Biochem. 73:47-52.

Jacobs, A. K., Lipka, V., Burton, R. A., Panstruga, R., Strizhov, N., Schulze-Lefert, P., and Fincher, G. B. 2003. An Arabidopsis callose synthase, GSL5, is required for wound and papillary callose formation. Plant Cell 15:2503-2513.

Johnston, C. A., Taylor, J. P., Gao, Y., Kimple, A. J., Grigston, J. C., Chen,
J.-G., Siderovski, D. P., Jones, A. M., and Willard, F. S. 2007. GTPase acceleration as the rate-limiting step in Arabidopsis G protein-coupled sugar signaling. Proc. Natl. Acad. Sci. U.S.A. 104:17317-17322.

Jones, A. M., and Assmann, S. M. 2004. Plants: The latest model system for G-protein research. EMBO (Eur. Mol. Biol. Organ.) Rep. 5:572 578.

Jones, A. M., Ecker, J. R., and Chen, J.-G. 2003. A reevaluation of the role of the heterotrimeric $\mathrm{G}$ protein in coupling light responses in Arabidopsis. Plant Physiol. 131:1623-1627.

Jones, J. C., Temple, B. R. S., Jones, A. M., and Dohlman, H. G. 2011. Functional reconstitution of an atypical $G$ protein heterotrimer and regulator of G protein signaling protein (RGS1) from Arabidopsis thaliana. J. Biol. Chem. 286:13143-13150.

Jørgensen, I. H. 1992. Discovery, characterization and exploitation of Mlo powdery mildew resistance in barley. Euphytica 63:141-152.

Kessler, S. A., Shimosato-Asano, H., Keinath, N. F., Wuest, S. E., Ingram, G., Panstruga, R., and Grossniklaus, U. 2010. Conserved molecular components for pollen tube reception and fungal invasion. Science 330:968-971

Kim, M. C., Panstruga, R., Elliott, C., Müller, J., Devoto, A., Yoon, H. W., Park, H. C., Cho, M. J., and Schulze-Lefert, P. 2002. Calmodulin interacts with MLO protein to regulate defence against mildew in barley. Nature 416:447-451.

Klopffleisch, K., Phan, N., Augustin, K., Bayne, R. S., Booker, K. S., Botella, J. R., Carpita, N. C., Carr, T., Chen, J.-G., Cooke, T. R., FrickCheng, A., Friedman, E. J., Fulk, B., Hahn, M. G., Jiang, K., Jorda, L., Kruppe, L., Liu, C., Lorek, J., McCann, M. C., Molina, A., Moriyama, E. N., Mukhtar, M. S., Mudgil, Y., Pattathil, S., Schwarz, J., Seta, S. Tan, M., Temp, U., Trusov, Y., Urano, D., Welter, B., Yang, J., Panstruga, R., Uhrig, J. F., and Jones, A. M. 2011. Arabidopsis G-protein interactome reveals connections to cell wall carbohydrates and morphogenesis. Mol. Syst. Biol. 7:532.

Kwaaitaal, M., Huisman, R., Maintz, J., Reinstädler, A., and Panstruga, R. 2011. Ionotropic glutamate receptor (iGluR)-like channels mediate MAMP-induced calcium influx in Arabidopsis thaliana. Biochem. J. 440:355-365

Lalonde, S., Sero, A., Pratelli, R. J., Pilot, G., Chen, J., Sardi, M. I., Parsa S. A., Kim, D.-Y., Acharya, B. R., Stein, E. V., Hu, H.-C., Villiers, F. Takeda, K., Yang, Y., Han, Y. S., Schwacke, R., Chiang, W., Kato, N., Loqu, D., Assmann, S. M., Kwak, J. M., Schroeder, J., Rhee, S. Y., and Frommer, W. B. 2010. A membrane protein/signaling protein interaction network for Arabidopsis version AMPv2. Front. Physiol. 1:24.

Legendre, L., Heinstein, P. F., and Low, P. S. 1992. Evidence for participation of GTP-binding proteins in elicitation of the rapid oxidative burst in cultured soybean cells. J. Biol. Chem. 267:20140-20147.

Lipka, V., Dittgen, J., Bednarek, P., Bhat, R., Wiermer, M., Stein, M., Landtag, J., Brandt, W., Rosahl, S., Scheel, D., Llorente, F., Molina, A., Parker, J., Somerville, S., and Schulze-Lefert, P. 2005. Pre- and postinvasion defenses both contribute to nonhost resistance in Arabidopsis. Science 310:1180-1183.

Liu, J. M., Ding, P. T., Sun, T. J., Nitta, Y., Dong, O., Huang, X. C., Yang, W., Li, X., Botella, J. R., and Zhang, Y. 2013. Heterotrimeric G proteins serve as a converging point in plant defense signaling activated by multiple receptor-like kinases. Plant Physiol. 161:2146-2158.

Llorente, F., Alonso-Blanco, C., Sánchez-Rodriguez, C., Jorda, L., and Molina, A. 2005. ERECTA receptor-like kinase and heterotrimeric G protein from Arabidopsis are required for resistance to the necrotrophic fungus Plectosphaerella cucumerina. Plant J. 43:165-180.

Lu, G., Wang, Z., Jones, A., and Moriyama, E. 2009a. 7TMRmine: A web server for hierarchical mining of $7 \mathrm{TMR}$ proteins. BMC Genomics $10: 275$

Lu, X., Tintor, N., Mentzel, T., Kombrink, E., Boller, T., Robatzek, S., Schulze-Lefert, P., and Saijo, Y. 2009b. Uncoupling of sustained MAMP receptor signaling from early outputs in an Arabidopsis endoplasmic reticulum glucosidase II allele. Proc. Natl. Acad. Sci. U.S.A. 106:22522-22527.

Maeda, K., Houjyou, Y., Komatsu, T., Hori, H., Kodaira, T., Ishikawa, A 2009. AGB1 and PMR5 contribute to PEN2-mediated preinvasion resistance to Magnaporthe oryzae in Arabidopsis thaliana. Mol. PlantMicrobe Interact. 22:1331-1340.

Mahady, G. B., Liu, C., and Beecher, C. W. W. 1998. Involvement of protein kinase and $\mathrm{G}$ proteins in the signal transduction of benzophenanthridine alkaloid biosynthesis. Phytochemistry 48:93-102.

Miles, G. P., Samuel, M. A., Jones, A. M., and Ellis, B. E. 2004. Mastoparan rapidly activates plant MAP kinase signaling independent of heterotrimeric G proteins. Plant Physiol. 134:1332-1336.

Moriyama, E., Strope, P., Opiyo, S., Chen, Z., and Jones, A. 2006. Mining the Arabidopsis thaliana genome for highly-divergent seven transmembrane receptors. Genome Biol. 7:R96.

Nishimura, M. T., Stein, M., Hou, B.-H., Vogel, J. P., Edwards, H., and 
Somerville, S. C. 2003. Loss of a callose synthase results in salicylic acid-dependent disease resistance. Science 301:969-972.

Oldham, W. M., and Hamm, H. E. 2008. Heterotrimeric G protein activation by G-protein-coupled receptors. Nat. Rev. Mol. Cell Biol. 9:60-71.

Pandey, S., and Assmann, S. M. 2004. The Arabidopsis putative G proteincoupled receptor GCR1 interacts with the $\mathrm{G}$ protein $\alpha$ subunit GPA1 and regulates abscisic acid signaling. Plant Cell 16:1616-1632.

Panstruga, R., and Schulze-Lefert, P. 2003. Corruption of host seven-transmembrane proteins by pathogenic microbes: A common theme in animals and plants? Microbes Infect. 5:429-437.

Perfus-Barbeoch, L., Jones, A. M., and Assmann, S. M. 2004. Plant heterotrimeric $\mathrm{G}$ protein function: Insights from Arabidopsis and rice mutants. Curr. Opin. Plant Biol. 7:719-731.

Piffanelli, P., Zhou, F., Casais, C., Orme, J., Jarosch, B., Schaffrath, U., Collins, N. C., Panstruga, R., and Schulze-Lefert, P. 2002. The barley MLO modulator of defense and cell death is responsive to biotic and abiotic stress stimuli. Plant Physiol. 129:1076-1085.

Rajasekhar, V. K., Lamb, C., and Dixon, R. A. 1999. Early events in the signal pathway for the oxidative burst in soybean cells exposed to avirulent Pseudomonas syringae pv. glycinea. Plant Physiol. 120:1137-1146.

Sanchez-Vallet, A., Ramos, B., Bednarek, P., López, G., PiślewskaBednarek, M., Schulze-Lefert, P., Molina, A. 2010. Tryptophan-derived secondary metabolites in Arabidopsis thaliana confer non-host resistance to necrotrophic Plectosphaerella cucumerina fungi. Plant J. 63:115-127.

Shiu, S.-H., and Bleecker, A. B. 2001. Plant receptor-like kinase gene family: Diversity, function and signaling. Sci. STKE 113:re22.

Straus, M. R., Rietz, S., Ver Loren van Themaat, E., Bartsch, M., and Parker J. E. 2010. Salicylic acid antagonism of EDS1-driven cell death is important for immune and oxidative stress responses in Arabidopsis. Plant J. 62:628-640.

Temple, B. R. S., and Jones, A. M. 2007. The plant heterotrimeric G-protein complex. Annu. Rev. Plant Biol. 58:249-266.

Thung, L., Trusov, Y., Chakravorty, D., and Botella, J. R. 2012. G $\gamma 1+$ G $\gamma 2$ $+\mathrm{G} \gamma 3=\mathrm{G} \beta$ : The search for the heterotrimeric G-protein $\gamma$ subunits is over. J. Plant Physiol. 169:542-545.

Torres, M. A., Morales, J., Sánchez-Rodríguez, C., Molina, A., and Dangl, J. L. 2013. Functional interplay between Arabidopsis NADPH oxidases and heterotrimeric G protein. Mol. Plant-Microbe Interact. 26:686-694.

Trusov, Y., Rookes, J. E., Chakravorty, D., Armour, D., Schenk, P. M., and Botella, J. R. 2006. Heterotrimeric G proteins facilitate Arabidopsis resistance to necrotrophic pathogens and are involved in jasmonate signaling. Plant Physiol. 140:210-220.

Trusov, Y., Rookes, J. E., Tilbrook, K., Chakravorty, D., Mason, M. G., Anderson, D., Chen, J.-G., Jones, A. M., and Botella, J. R. 2007. Het- erotrimeric $G$ protein $\gamma$ subunits provide functional selectivity in G $\beta \gamma$ dimer signaling in Arabidopsis. Plant Cell 19:1235-1250.

Ullah, H., Chen, J.-G., Temple, B., Boyes, D. C., Alonso, J. M., Davis, K. R., Ecker, J. R., and Jones, A. M. 2003. The $\beta$-subunit of the Arabidopsis $\mathrm{G}$ protein negatively regulates auxin-induced cell division and affects multiple developmental processes. Plant Cell 15:393-409.

Urano, D., and Jones, A. M. 2013. "Round up the usual suspects." A comment on nonexistent plant G protein-coupled receptors. Plant Physiol. 161:1097-102

Urano, D, Jones, J. C., Wang, H., Matthews, M., Bradford, W., Bennetzen, J. L., and Jones, A. M. 2012. G protein activation without a GEF in the plant kingdom. PLoS Genet. 8:e1002756.

Vera-Estrella, R., Higgins, V. J., and Blumwald, E. 1994. Plant defense response to fungal pathogens (II. G-protein-mediated changes in host plasma membrane redox reactions). Plant Physiol. 106:97-102.

Vogel, J. P., Raab, T. K., Schiff, C., and Somerville, S. C. 2002. PMR6, a pectate lyase-like gene required for powdery mildew susceptibility in Arabidopsis. Plant Cell 14:2095-2106.

Vogel, J. P., Raab, T. K., Somerville, C. R., and Somerville, S. C. 2004. Mutations in PMR5 result in powdery mildew resistance and altered cell wall composition. Plant J. 40:968-978.

Wolter, M., Hollricher, K., Salamini, F., and Schulze-Lefert, P. 1993. The mlo resistance alleles to powdery mildew infection in barley trigger a developmentally controlled defence mimic phenotype. Mol. Gen. Genet. 239:122-128.

Zhang, J., Shao, F., Li, Y., Cui, H., Chen, L., Li, H., Zou, Y., Long, C., Lan, L., Chai, J., Chen, S., Tang, X., and Zhou, J.-M. 2007. A Pseudomonas syringae effector inactivates MAPKs to suppress PAMP-induced immunity in plants. Cell Host Microbe 1:175-185.

Zhang, L., Hu, G., Cheng, Y., and Huang, J. 2008. Heterotrimeric G protein alpha and beta subunits antagonistically modulate stomatal density in Arabidopsis thaliana. Dev. Biol. 324:68-75.

Zhang, W., He, S. Y., and Assmann, S. M. 2008. The plant innate immunity response in stomatal guard cells invokes G-protein-dependent ion channel regulation. Plant J. 56:984-996.

Zhang, W., Jeon, B. W., and Assmann, S. M. 2011. Heterotrimeric G-protein regulation of ROS signalling and calcium currents in Arabidopsis guard cells. J. Exp. Bot. 62:2371-2379.

\section{AUTHOR-RECOMMENDED INTERNET RESOURCES}

ATTED-II database: atted.jp

T-DNA Express Arabidopsis gene mapping tool:

signal.salk.edu/cgi-bin/tdnaexpress 